\title{
Sudan: Midyear Review of the 2005 Staff-Monitored Program
}

This paper on the midyear review of the 2005 staff-monitored program for Sudan was prepared by a staff team of the International Monetary Fund as background documentation for the periodic consultation with the member country. It is based on the information available at the time it was completed on November 8, 2005. The views expressed in this document are those of the staff team and do not necessarily reflect the views of the government of Sudan or the Executive Board of the IMF.

The policy of publication of staff reports and other documents by the IMF allows for the deletion of market-sensitive information.

To assist the IMF in evaluating the publication policy, reader comments are invited and may be sent by e-mail to publicationpolicy@imf.org.

Copies of this report are available to the public from

International Monetary Fund $\bullet$ Publication Services

700 19th Street, N.W. • Washington, D.C. 20431

Telephone: (202) 6237430 • Telefax: (202) 6237201

E-mail: publications@imf.org • Internet: http://www.imf.org

Price: $\$ 15.00$ a copy

\section{International Monetary Fund Washington, D.C.}



INTERNATIONAL MONETARY FUND

SUDAN

Midyear Review of the 2005 Staff-Monitored Program

Prepared by the Middle East and Central Asia and Policy Development and Review Departments

Approved by Lorenzo L. Pérez and Matthew Fisher

November 8, 2005

Contents

Page

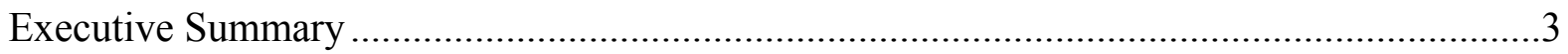

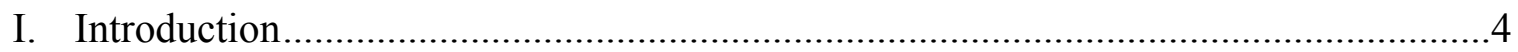

II. Recent Developments and Performance Under the Program .......................................

III. Policy Discussions and Outlook for the Remainder of 2005 ……................................7

IV. Key Near-Term Challenges for the New Government ..............................................10

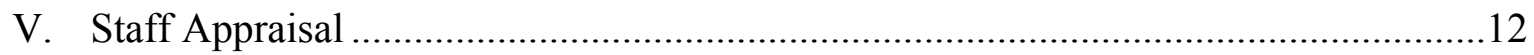

Text Boxes

Box 1. Central Government Transfers to Subnational Governments ........................................

Text Tables

1. Selected Fiscal Indicators of the Central Government ..................................................5

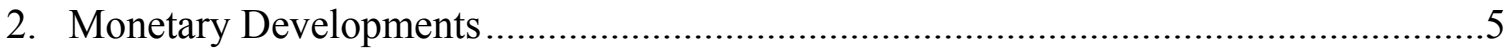

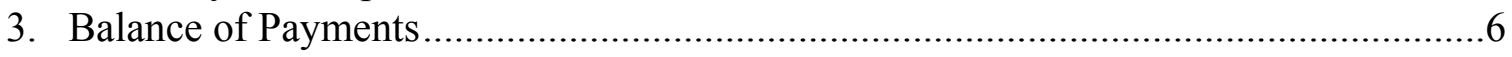

Text Figures

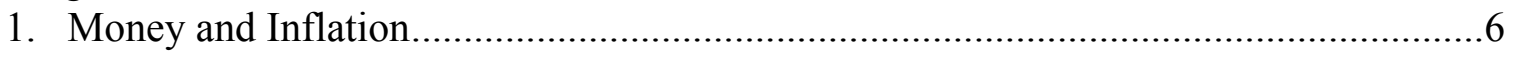

2. Nominal and Real Effective Exchange Rates ………..............................................6

Tables

1. Selected Economic and Financial Indicators, 2001-06 ….........................................14

2. Central Government Operations 2003-05 ……….............................................15

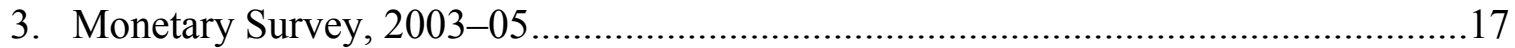

4. Monetary Authorities' Accounts, 2003-05 ……………………….......................18

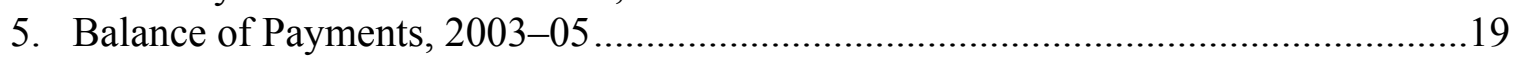

6. Quantitative Targets Under the Staff-Monitored Program ..........................................20

7. Structural Benchmarks under the Staff-Monitored Program .......................................21

8. Medium-Term Macroeconomic Scenario, 2004-10 ………………………..............22 


\section{Appendixes}

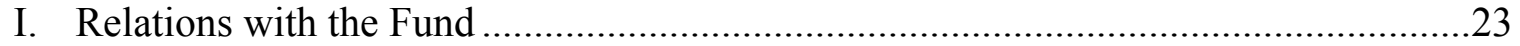

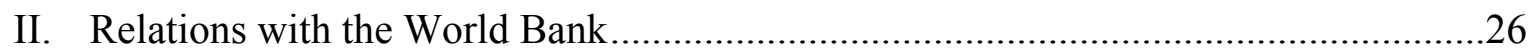

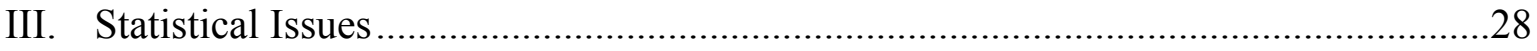




\section{EXECUTIVE SUMMARY}

In the context of a very difficult political and security situation, a comprehensive peace agreement between the government and the Sudan People's Liberation Movement is being implemented. The country has a new constitution, and a new government of national unity was formed after more than 20 years of civil war with the south. At this critical juncture, the government has the opportunity to bring about a number of important economic and political reforms to foster peace and economic development in the whole country.

Economic growth remains robust, but inflationary pressures reemerged during the first seven months of the year. The 12-month rate of inflation rose from 7.3 percent in December 2004 to 13.9 percent in July 2005. Unanticipated government expenditures, including a subsidy on domestic fuel consumption emanating from fixed local prices, resulted in a weaker-than-expected fiscal performance and contributed to a larger-than-programmed expansion in monetary aggregates.

After a mixed performance under the staff-monitored program during the first half of the year, the authorities are taking corrective measures to bring the program back on track. They imposed strict controls on nonpriority government spending, tightened monetary policy, and committed to stop nonconcessional borrowing. The 12-month rate of inflation fell to an estimated 8 percent in October. The authorities remain committed to implement the remaining structural measures under the program. They are also considering raising domestic fuel prices later in the year or in early 2006 with a view to improving the fiscal position while at the same time minimizing the impact of the price increase on the poor.

Looking ahead, while higher oil production in 2006 will help finance additional expenditures, fiscal policy will need to be part of a macroeconomic framework conducive to low inflation. Expenditures should be allocated to priority sectors and high-return projects, and fuel subsidies should be reduced. At the same time, the oil saving account will continue to play an important role in providing self-insurance against an oil price shock. Lastly, monetary policy should continue to focus on controlling reserve money growth and allowing for further flexibility in the pricing of securities and foreign exchange.

The authorities are also encouraged to concentrate their efforts on improving oil sector transparency, conducting a public expenditure review, building capacity and accountability in the states (including the government of Southern Sudan), continuing with banking system reforms, and reviewing the system of tax incentives. The staff shares the authorities' concerns about profitability in non-oil sectors and encourages them to carry out reforms that improve the business environment. Lastly, the national unity government is expected to prepare an interim poverty reduction strategy. 


\section{INTRODUCTION}

1. In concluding the 2005 Article IV consultation on April 29, 2005, Executive Directors commended the authorities for pursuing prudent fiscal and monetary policies and implementing wide-ranging reforms in recent years. Directors emphasized the importance of keeping inflation low, prioritizing expenditures and strengthening public expenditure management, increasing transparency in the operations of the state-owned oil company, and containing nonconcessional borrowing.

2. A staff team visited Khartoum from August 30 through September 8, 2005 to conduct the midyear review of the Staff-Monitored Program (SMP) and revise the program in light of changes in oil sector assumptions, budget developments, and the outlook for the remainder of the year. ${ }^{1}$ The discussions were concluded on September 25 at the time of the Annual Meetings. This report summarizes the outcome of the discussions and the revised program.

\section{Recent Developments And Performance Under the Program}

\section{After some delay, the government and the Sudan People's Liberation Movement} (SPLM) began implementing the peace agreement signed earlier this year. The unexpected death of the SPLM leader Dr. Garang in late July and the ensuing ethnic unrest in Khartoum contributed to the delay. A new constitution was approved in August and the new government of national unity was formed in September. The government includes Mr. Salva Kiir (now head of the SPLM) as the First Vice President as well as ministers from the SPLM, other parties from the south, and some opposition parties from the north.

\section{The situation in Darfur has been precarious and pressure is mounting for a} political solution to the conflict. In recent months, the UN has reported a number of attacks by bandits on civilians and humanitarian workers, clashes among rebel factions, kidnappings, and killing of African Union peacekeepers. Peace talks between the government and the two main rebel groups have moved slowly this year, and the international community is stepping up the pressure to find a political solution to the conflict. However, major issues such as the sharing of power and resources have yet to be resolved.

\section{The non-oil economy has been growing at a fast pace this year, but inflationary} pressures have been a concern. Agricultural output is on the rise and other non-oil activities such as construction and services are booming. Oil output is also growing, but at a slower pace than previously anticipated because of a delay in production from two new fields. For the year as a whole, real GDP growth is projected at 8.2 percent (Table 1). The 12-month rate of inflation rose from 7.3 percent in December 2004 to 13.9 percent in July 2005. The increase in inflation reflected a combination of supply constraints (e.g.

\footnotetext{
${ }^{1}$ The mission met with the Minister of Finance, Mr. El-Zubeir Ahmed El-Hassan; the governor of the Bank of Sudan, Mr. Sabir Mohammad Hassan; other senior officials; and representatives of the private sector, the donor community, and the UN. The staff team comprised Mr. Gelbard (head), Mr. Ilahi, Mr. Al-Ghelaiqah, Ms. Maseeh (all MCD); and Mr. Hussain (PDR). Mr. de Schaetzen (the Fund's resident representative in Sudan) worked jointly with the mission and finalized the arrangements for opening the resident office in Khartoum.
} 
bottlenecks at the port, lags in supply response) and expansionary policies. ${ }^{2}$ Since then, a more prudent policy stance coupled with improvements in customs procedures helped to alleviate these pressures, and inflation fell to an estimated 8 percent in October.

\section{Despite a shortfall in transfers to the south, unanticipated expenditures led to a weaker than expected fiscal performance. Revenues were roughly as expected, but} expenditures exceeded the programmed level mainly because of the emergence of a large subsidy on domestic fuels. ${ }^{3}$ In addition, spending on relief and security operations in Darfur were higher than expected, and the authorities adopted a policy to repay the entire stock of domestic arrears in 2005. ${ }^{4}$ The higher level of expenditure, combined with a shortfall in external financing, led to higher-than-programmed financing from the central bank (Table 2). Lastly, transfers to the south lagged because of delays in the formation of the unity government.

\begin{tabular}{|lcc|}
\hline \multicolumn{3}{|c|}{$\begin{array}{c}\text { Selected Fiscal Indicators of the Central Government } \\
\text { (Cash basis, in percent of annual GDP) }\end{array}$} \\
\hline \multicolumn{3}{|c}{ Jan-Jun 2005} \\
Program & Actual \\
\hline Revenue & 9.6 & 9.8 \\
Expenditure & 9.8 & 9.9 \\
of which: fuel subsidy & 0.0 & 1.4 \\
$\quad$ general reserve & 0.6 & 1.2 \\
transfers to states & 3.5 & 1.9 \\
Balance $\quad-0.2$ & 0.0 \\
External financing & 0.3 & 0.1 \\
Domestic financing & -0.1 & 0.0 \\
of which: central bank & -0.5 & 0.0 \\
repayment of arrears (-) & 0.1 & 0.5 \\
\hline Source: Sudanese authorities, and Fund staff estimates. \\
\hline
\end{tabular}

\section{Monetary conditions became looser during the first half of the year while the} dinar continued to appreciate. Higher central bank financing to the government and capital inflows contributed to high monetary growth (Tables 3 and 4). Despite some efforts to mop up liquidity in the second quarter of the year, the central bank did not completely sterilize these trends because of concern about the effects of higher rates of return on securities and exchange rate appreciation on non-oil

\begin{tabular}{|lrr|}
\hline \multicolumn{3}{|c|}{$\begin{array}{c}\text { Monetary Developments } \\
\text { (Change in percent) }\end{array}$} \\
\hline & \multicolumn{2}{c|}{ June 2004-June 2005 } \\
\cline { 2 - 3 } Prog. & Act. \\
\hline Reserve money & 32.9 & 40.0 \\
Net foreign assets & 49.1 & 86.0 \\
Net domestic assets & 16.4 & 9.5 \\
Broad money & 29.7 & 40.6 \\
Of which: credit to the government & -64.3 & -34.5 \\
\hline Sources: Sudanese authorities; and Fund staff estimates. \\
\hline
\end{tabular}

\footnotetext{
${ }^{2}$ Prices for food, water, electricity, and housing rose faster than other prices during this period.

${ }^{3}$ The prices of domestically consumed fuels were set at the time the 2005 budget was formulated and have remained unchanged since then despite rising international prices. These prices are traditionally set by decree and are not automatically adjusted in response to changing market conditions. However, under the peace agreement, crude oil sales to domestic refineries have to be at world prices. The state-owned oil company discounts the difference between domestic and world prices when it transfers oil revenue to the treasury. The staff has advised the authorities to classify these (now implicit) subsidies as a budget expenditure item (Table 3).

${ }^{4}$ Darfur-related spending is classified as part of the general reserve category. In early 2005 , the authorities finalized an audit of expenditure arrears accrued over the past few years. They subsequently issued payment obligations for the stock of arrears (equivalent to 0.7 percent of GDP) redeemable by end-2005. More than half of that amount was paid by end-June.
} 
exports. ${ }^{5}$ During the first eight months of this year, the nominal and the real effective exchange rates appreciated by 8 and 17 percent, respectively.
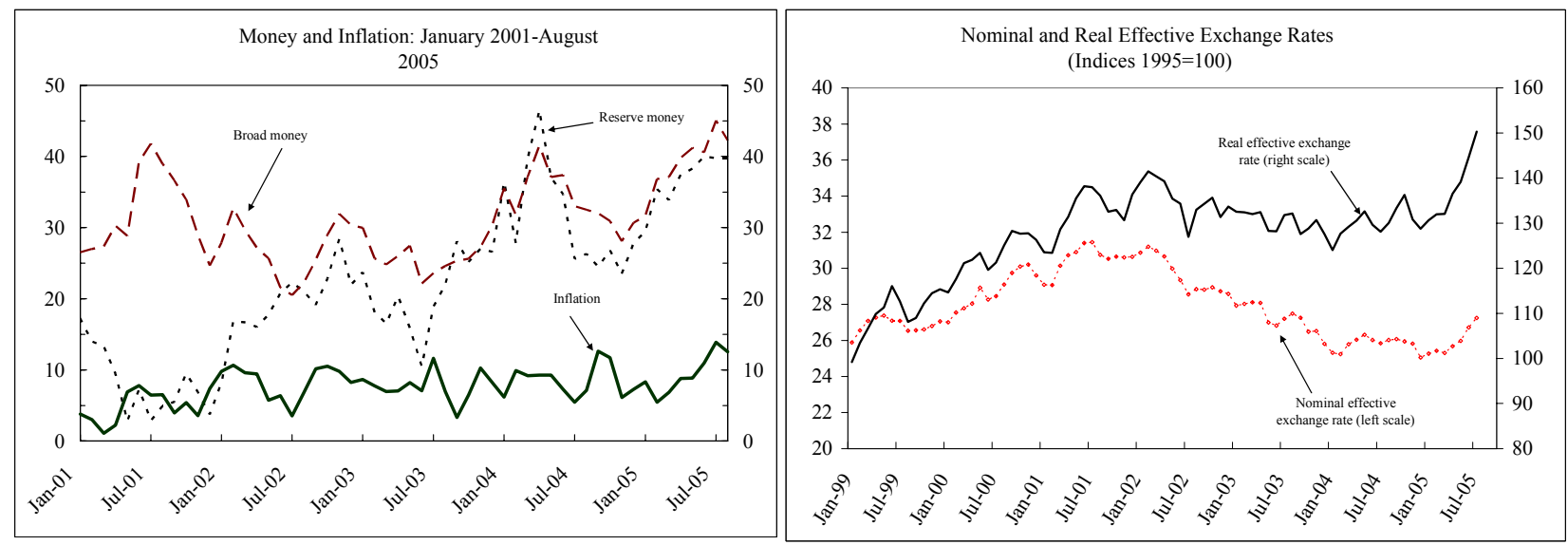

8. Despite a weaker than expected current account performance, higher capital inflows supported the balance of payments during the first half of the year. Higher world oil prices contributed to an increase in oil export revenue, but the current account worsened because of a surge in imports of machinery and manufactured goods and weak non-oil exports. The latter reflects a combination of higher domestic demand, transportation bottlenecks, and the recent appreciation of the exchange rate. Overall, the balance of payments and official international reserves benefited from strong capital inflows including foreign direct investment. At end-June 2005, international reserves stood at the equivalent of 2.4 months of imports of goods and services (Table 4).

\begin{tabular}{|c|c|c|c|}
\hline \multicolumn{4}{|c|}{$\begin{array}{l}\text { Balance of Payments, First Half of } 2004 \text { and } 2005 \\
\text { (Cash basis, in millions of U.S. dollars unless otherwise indicated) }\end{array}$} \\
\hline & \multirow{3}{*}{$\begin{array}{r}2004 \\
\text { Jan.-Jun. } \\
\text { Actual }\end{array}$} & \multicolumn{2}{|c|}{2005} \\
\hline & & Jan.- & \\
\hline & & Prog. & Est. \\
\hline Trade balance & 63.0 & -80.0 & -70.0 \\
\hline Exports (f.o.b.) & 1,673 & 2,029 & 2,308 \\
\hline Non-oil & 377 & 374 & 304 \\
\hline Imports (f.o.b.) & $-1,610$ & $-2,109$ & $-2,378$ \\
\hline Current account & -339 & -663 & -841 \\
\hline In percent of GDP, annualized & -3.2 & -5.2 & -6.0 \\
\hline Capital and financial accounts & 555 & 638 & 940 \\
\hline In percent of GDP, annualized & 5.2 & 5.0 & 6.7 \\
\hline Change in official reserves (increase, -) & -312 & -180 & -285 \\
\hline Oil exports (in million barrels) & 37.5 & 47.0 & 40.7 \\
\hline
\end{tabular}

9. Performance under the program was mixed. Two of the four quantitative targets for end-June 2005 were missed and the end-December 2005 target on nonconcessional borrowing was exceeded by a large margin (Table 6). ${ }^{6}$ The ceiling on domestic financing of the government was breached because of the aforementioned fiscal expansion, while the target on international reserves was missed because of higher-than-programmed imports and

\footnotetext{
${ }^{5}$ Sudan has a managed floating exchange rate regime.

${ }^{6}$ In the first half of 2005 , the government contracted nonconcessional external financing for US\$803 million compared to the annual program target of US\$150 million. These loans, primarily from China, will finance water and electricity rehabilitation projects over a number of years.
} 
foreign exchange payments to the SPLM (arising from its share of oil revenues) as well as lower-than-projected export volumes. ${ }^{7}$ On the structural side, all the end-June measures were carried out on time, including the introduction of an auction system for government certificates, the formulation of a program to introduce commercial accounting standards in the state-owned oil sector company, and the creation of a medium-size taxpayers' unit (Table 7).

\section{The authorities indicated their intention to remove two remaining exchange} restrictions subject to Fund jurisdiction. Sudan accepted the obligations of Article VIII, Sections 2, 3 and 4 of the Fund's Articles of Agreement on October 29, 2003._Subsequently, the staff conducted a comprehensive review of Sudan's exchange system in connection with its Article VIII acceptance. Based on the findings and indications of a staff visit in September 2005, the authorities have committed to removing the exchange restrictions arising from (i) the prohibition that applies to importers in arrears with valid import licenses from executing payments and transfers for import transactions and (ii) the multiple currency practice arising from the use of a historic buying rate for the resale of export proceeds.

\section{Policy Discussions ANd OUTlook For THE ReMAinder OF 2005}

\section{A revised financial program for the second half of $\mathbf{2 0 0 5}$ was formulated with the} goal of containing inflation. Average inflation for 2005 is targeted at 10.5 percent compared to 7.5 percent under the original program, and the 12-month rate of inflation is projected at 8-9 percent. Absent corrective actions, the authorities estimated that the 12-month rate of inflation could reach between 15 and 20 percent by year-end.

\section{The authorities have set aside their plans for additional nonconcessional}

borrowing in the second half of this year. The staff conveyed its reservations about high nonconcessional borrowing given that such borrowing is expensive and could complicate debt relief efforts in the future. The authorities deem this borrowing as essential for financing high priority projects in the absence of access to concessional loans and tight budgetary conditions. In the end, the authorities expressed their intention to freeze new nonconcessional borrowing for the remainder of the year and indicated that they will limit the drawdown of the recently contracted facilities.

\section{Oil and non-oil fiscal revenues will be higher than in the original program.} Despite a delay in oil production from new fields, oil revenues are expected to be 22 percent higher than in the original program because of the increase in oil prices. ${ }^{8}$ Reflecting robust

\footnotetext{
${ }^{7}$ As part of the peace agreement, the south is expected to receive transfers proportional to the value of oil production. The central bank has set a separate account for the government of the south where these balances are deposited. As the government of national unity has now been formed, the parties are expected to clarify the accounting procedures for these transactions. Between January and June, the government transferred US $\$ 80$ million to the SPLM. At the time the program was formulated, it was assumed that these payments would be effected in a newly created domestic currency.

${ }^{8}$ For 2005 , the price of Sudan's oil is projected at US\$52 per barrel compared to US\$34 in the original program.
} 
non-oil GDP growth and expected improvements in tax administration, the non-oil revenue forecast has also been revised upward (Table 2).

\section{Understandings were reached to restrain growth in nonpriority expenditures.}

The continuing security and relief operations in Darfur are likely to result in higher-thanprogrammed expenditures in the general reserve category by year-end. However, the authorities intend to limit outlays in the wages and salaries and in the goods and services categories while keeping social and capital expenditures at the budgeted level. ${ }^{9}$ These steps are needed to limit the domestic financing of the fiscal deficit and ensure a reduction of reserve and broad money growth in the second half of the year (Table 4).

\section{While fuel subsidies impose a large fiscal cost, the authorities argued that there} was little room for immediate action on the problem. The authorities were hesitant to raise prices shortly after the inauguration of the government of national unity and were concerned about the social repercussions of such a move at this delicate moment. They believed that the best approach would be to increase prices gradually and indicated that they will likely start doing this toward the end of the year or in early 2006. The authorities also intend to prepare, in consultation with Fund staff, a medium-term strategy that would include a more automatic adjustment of fuel prices in response to changes in market conditions.

\section{The projected fiscal deficit for $\mathbf{2 0 0 5}$ is similar to the one in the original program,} but the composition of financing will be different. Fiscal revenues benefit from higher international oil prices, but expenditures are projected to be higher as well (Table 2). Lowerthan-programmed oil output and external financing will be offset by the use of deposits from the old oil stabilization account as well as a higher benchmark price of oil. ${ }^{10}$ As envisaged in the peace agreement with the south, the authorities set up in January 2005 a new oil savings account shared between the central government and the government of Southern Sudan. ${ }^{11}$ The balances of the old oil savings account initially remained as part of government deposits, but the authorities decided to use these proceeds to finance additional spending, mainly capital expenditures. Lastly, as part of a fiscal decentralization plan, transfers to the south and other states will increase drastically in 2005 compared to previous years (Box 1).

\footnotetext{
${ }^{9}$ Social spending has been budgeted at about 1.2 percent of GDP. The authorities' definition of social spending is quite narrow, and discussions between the authorities and the World Bank are underway to come up with a more comprehensive definition of pro-poor spending.

${ }^{10}$ The benchmark price is used to channel oil revenues to the budget. It was increased from US $\$ 30$ per barrel in the first half of this year to US $\$ 45$ per barrel in the second half. The difference between this price and the oil export price determines the amount accumulated in the oil savings account.

${ }^{11}$ In 2005, the new oil savings account is projected to accumulate the equivalent of 2 percent of GDP.
} 


\section{Box 1. Central Government Transfers to Subnational Governments}

The ongoing increase in fiscal expenditures and in the non-oil fiscal deficit reflects an expansion in the role of the government. However, a large part of the increase is attributed to entitlements arising from the peace agreement and fiscal decentralization. Central government revenues have risen in recent years, driven by tax reforms and higher oil revenues. Despite the higher revenues, the fiscal space of the central government has not increased in 2005 because of large transfers to the government of Southern Sudan and to other states.

The north-south peace agreement stipulates that about 40 percent of oil revenues would be transferred to the south and the war-affected areas. In addition, the government decided in late 2004 to move ahead with an ambitious fiscal decentralization plan that entails a rapid increase in transfers to the remaining states. The plan aims at empowering the states with a view to increasing pro-poor spending and alleviating regional disparities.

17. The authorities have been tightening monetary policy in the second half of the year. Reserve money growth (12-month basis) fell from 40 percent in June to an estimated 32 percent in September and is projected to reach 30 percent in December. The path for broad money growth is expected to follow a similar profile (Table 3). The central bank has been mopping up liquidity through open market sales of government securities and foreign exchange as well as limits on its lending to commercial banks.

18. The balance of payments will continue to benefit from higher oil export revenues and strong capital inflows. The trends observed during the first half of the year are likely to continue, namely higher export revenue on account of high oil prices, higher import demand, strong private capital inflows (mainly foreign direct investment), and a further reserve build up to about 2.9 months of imports of goods and services (Table 5).

\section{The authorities expressed their commitment to implement the remaining} structural measures under the staff-monitored program. By end-December, the authorities are expected to convert the 2006 budget into Government Finance Statistics format. Another important measure is the preparation of a three-year tariff reform program.

20. The authorities are concerned about profitability in non-oil sectors and recognize the need to improve the business environment. The oil sector boom coupled with the projected increase in government spending will constrain profitability in non-oil 
tradable sectors through real exchange rate appreciation and higher borrowing costs. To deal with this problem, the authorities agreed on the urgency to accelerate structural reforms and develop the public infrastructure with a view to lowering domestic costs and improving the business environment. ${ }^{12}$

21. Financial sector reforms are proceeding. The authorities have already prepared a financial sector reform program in light of recent FSAP recommendations (end-December benchmark). They also submitted a request for technical assistance that the Fund will coordinate with the World Bank. As envisaged in the peace agreement, the authorities drafted a plan to restructure and decentralize the central bank and submitted to Parliament legislation to change its legal and operational structure (including setting up a branch in south Sudan). Regarding the new currency, the target date for its introduction has been changed from October 2005 to June 2006 because of technical delays and uncertainty about financing sources.

\section{KEY NEAR TERM CHALLENGES FOR THE NEW GOVERNMENT}

\section{In 2006, higher oil production will help finance additional expenditures, but} resources should be allocated to priority sectors and high-return projects within a macroeconomic framework conducive to low inflation. A large increase in oil output next year will come at an opportune time given Sudan's infrastructure and pro-poor spending needs and will permit a commensurate increase in transfers to the south and other states to foster national unity (Table 8). At the same time, self-insuring against an oil price shock through building up savings in the oil savings account would be critical, as well as donor support to finance reconstruction projects. The authorities are also aware that capacity constraints in several areas call for cautious and prioritized increases in spending. Equally important will be for them to effect an increase in fuel prices that will reduce the burden of the subsidy on the budget while at the same time minimizing the impact of the price increase on the poor. ${ }^{13 ; 14}$

\section{In addition to sound fiscal and monetary policies, the authorities are expected to focus on the following structural reforms:}

Import tariffs. The forthcoming import tariff reform program should be ambitious enough (especially in reducing the top tariff rate of 45 percent) to improve competitiveness and foster integration with the world economy.

\footnotetext{
${ }^{12}$ In addition to priority fiscal reforms, the authorities are planning to conduct an investment climate assessment in collaboration with the World Bank within the context of a broader review of the environment for private sector growth.

${ }^{13}$ The lack of household survey data prevents the carrying out of a poverty and social impact analysis.

${ }^{14}$ Discussions between the staff and the authorities on the 2006 budget will take place in November and will include the plan for adjusting fuel prices. The authorities indicated their intention to discuss a staff monitored program for 2006; these discussions are expected to be completed at the time of the next Article IV consultation discussions planned for February 2006.
} 
Tax incentives. Building on the progress already made to reduce tax exemptions, a review of the system of incentives could offer ways to boost non-oil revenue and distribute the tax burden more evenly and transparently.

> Public expenditure and fiscal decentralization. This involves a public expenditure review as well as urgent efforts to build capacity, transparency, and accountability in both the central government and the states. ${ }^{15}$

$>$ Oil sector governance. The National Petroleum Commission - a high-level body envisaged under the comprehensive peace agreement - will be expected to design a strategy for the oil sector that will improve governance and transparency and bring about much-needed reforms to the state-owned oil company and its subsidiaries.

$>$ Banking system restructuring. This involves the reorganization of the central bank, the introduction of a new currency and a dual banking system (Islamic banking in the north and conventional banking in the south), and commercial bank restructuring through mergers and privatization.

24. Sudan's external debt remains unsustainable. The end-2004 stock of external public debt is estimated at US\$26 billion in nominal terms (904 percent of exports of goods and services in net present value terms), of which about 86 percent is in arrears. Restoring Sudan's external viability would require exceptional debt relief, including under the HIPC Initiative and the Multilateral Debt Relief Initiative. The strategy for resolving Sudan's debt and arrears problems is discussed in a companion Board paper. ${ }^{16}$

25. Lastly, the national unity government is expected to increase its interaction with donors and prepare an interim poverty reduction strategy. The UN is leading efforts to coordinate donor activity in Sudan, and the World Bank has established two multi-donor trust funds to finance projects of both the national government and the government of the south. Following up on the road map provided by the Joint Assessment Mission and on the report recently prepared jointly with the World Bank and the UN on poverty and the Millennium Development Goals, the authorities are planning to finalize an interim poverty reduction strategy by mid-2006. ${ }^{17}$ Cognizant of the daunting challenges these reforms

\footnotetext{
${ }^{15}$ The World Bank will coordinate the preparation of the public expenditure review, the first for Sudan. The review will primarily cover state expenditures (since much of the responsibility for social and local development programs is being decentralized) but it will also cover the composition of central government expenditures including pro-poor expenditures and public investment, comprehensiveness of the fiscal accounts, public sector financial management, and oil and non-oil revenue mobilization.

${ }^{16}$ Sudan — Fundamental Issues in Resolving External Debt Problems and Achieving Debt Sustainability_Further Considerations.

${ }^{17}$ Semiannual consultative group meetings (the Sudan Consortium) have been scheduled between the government and donors to monitor progress in the implementation of the peace agreement and in the actions embedded in the Joint Assessment Mission report. The latter was prepared earlier this year by the government in collaboration with the UN, the World Bank, and the Fund. The UN has requested continued engagement by the staff in the areas of Fund competence.
} 
involve, the authorities expect to receive financial and technical assistance from donors and international agencies, including the Fund.

\section{Staff Appraisal}

26. Despite unexpected developments and significant challenges, the peace agreement with the south is being implemented. The sudden death of Dr. Garang and associated political and social tensions are regrettable developments, but the government and the SPLM have overcome these challenges by establishing the government of national unity and moving ahead with the implementation of the peace agreement. This has been a major achievement, and the new government will now have the opportunity to help bring about peace and economic development to the whole country.

27. The non-oil economy has been expanding rapidly this year, but the budget and monetary policy have been subject to increased strain and inflation has been edging upwards. There has been an expanding subsidy on fuel products as domestic fuel prices have not been increased following the recent upsurge in world oil prices as well as higher-thanbudgeted spending in certain categories. As a result, there have been some deviations from the end-June quantitative targets under the staff-monitored program. In addition, the reluctance to sterilize government spending and external inflows in the first half of the year out of fear of excessive exchange rate appreciation also contributed to loose monetary conditions and the above-mentioned inflationary pressures.

28. In the context of a very difficult political situation, the authorities are taking corrective actions that the staff believes are sufficient to bring the program back on track. A reduction in fuel subsidies has been delayed because of political uncertainties at the beginning of the implementation of the peace agreement. In this context, renewed fiscal restraint in other areas as envisaged in the revised program is a welcome step. In addition, recent steps by the central bank to control reserve money growth and allow for further flexibility in the pricing of securities and foreign exchange are consistent with the objective of containing inflation pressures.

29. The staff urges the authorities to adhere to their commitment to stop further nonconcessional borrowing in the second half of the year. While these loans might have been justified in the past given the need for financing oil sector investments and other infrastructure projects, the expected increase in oil-related flows and donor assistance (grants and concessional loans) in coming years should be sufficient to attend the country's investment needs. Furthermore, nonconcessional or other forms of oil-guaranteed borrowing could complicate Sudan's eventual debt relief discussions with creditors.

30. Further actions will be needed in $\mathbf{2 0 0 6}$ to safeguard macroeconomic stability. Oil production and revenues are expected to increase rapidly, and the authorities will have the opportunity to devote additional resources for pro-poor spending and infrastructure projects. At the same time, the 2006 budget will need to be carefully designed to balance the need to

preserve macroeconomic stability, avoid excessive crowding out of the private sector, meet expenditure priorities, and carry out an appropriate reduction in fuel subsidies that minimizes 
the impact on the poor. In addition, building up balances in the oil saving account would be important for safeguarding against a sudden shock to international oil prices. Finally, a prudent monetary policy will be required to ensure that inflation objectives are achieved.

31. Sudan's structural reform efforts in recent years have yielded positive benefits, but much more remains to be done. The oil sector boom coupled with an expansionary fiscal policy will likely constrain profitability in non-oil tradable sectors through real exchange rate appreciation and higher borrowing costs. In this context, the staff encourages the authorities to focus on the removal of transportation and other bottlenecks and press ahead with the structural reform agenda. The latter includes a further rationalization of tax incentives, an ambitious import-tariff reform program, appropriate investment in infrastructure, financial sector restructuring, and the implementation of a strategy to reduce barriers to private sector development. Lastly, the authorities should pursue additional reforms to improve transparency in the oil sector including adopting modern accounting standards in the state-owned oil company and its subsidiaries. 
Table 1. Sudan: Selected Economic and Financial Indicators, 2001-06

\begin{tabular}{|c|c|c|c|c|c|c|c|}
\hline & \multirow[t]{2}{*}{2001} & \multirow[t]{2}{*}{2002} & \multirow[t]{2}{*}{2003} & \multirow[t]{2}{*}{2004} & \multicolumn{2}{|c|}{2005} & \multirow{2}{*}{$\begin{array}{r}2006 \\
\text { Proj. } 2 /\end{array}$} \\
\hline & & & & & Prog. 1/ & $\begin{array}{r}\text { Rev. } \\
\text { Prog. } 2 /\end{array}$ & \\
\hline & \multicolumn{7}{|c|}{ (Annual changes in percent, unless otherwise indicated) } \\
\hline \multicolumn{8}{|l|}{ Production, population, and prices } \\
\hline Nominal GDP (in billions of Sudanese dinars, at market prices) & 3,452 & 3,964 & 4,580 & 5,535 & 6,299 & 6,912 & 8,570 \\
\hline Nominal GDP (in millions of U.S. dollars) & 13,363 & 15,054 & 17,550 & 21,463 & 23,891 & 28,050 & 37,261 \\
\hline Crude oil production (in thousands of barrels per day) & 209 & 232 & 262 & 288 & 391 & 312 & 510 \\
\hline Population (in millions) & 31.9 & 32.7 & 33.6 & 34.5 & 35.4 & 35.4 & 36.3 \\
\hline GNP per capita (in U.S. dollars) & 400 & 440 & 499 & 590 & 751 & 790 & 950 \\
\hline Real GDP & 6.4 & 6.1 & 5.1 & 5.2 & 8.3 & 8.2 & 13.4 \\
\hline Oil & 21.6 & 24.7 & 13.0 & 9.9 & 35.6 & 8.2 & 63.6 \\
\hline Non-oil & 5.3 & 4.6 & 4.4 & 4.8 & 5.6 & 8.2 & 7.8 \\
\hline Consumer prices (average) & 4.9 & 8.3 & 7.7 & 8.4 & 7.5 & 10.5 & 7.0 \\
\hline Consumer prices (end of period) & 7.4 & 8.3 & 8.3 & 7.3 & 8.0 & 9.1 & 6.4 \\
\hline & \multicolumn{7}{|c|}{ (In percent of GDP) } \\
\hline Investment and saving & & & & & & & \\
\hline Gross investment & 17.6 & 19.4 & 20.0 & 22.5 & 24.4 & 21.9 & 23.8 \\
\hline Government & 2.3 & 3.0 & 3.0 & 5.0 & 6.8 & 4.9 & 6.6 \\
\hline Nongovernment & 15.3 & 16.4 & 17.0 & 17.5 & 17.7 & 17.8 & 17.2 \\
\hline Gross national saving & 7.9 & 13.3 & 15.3 & 18.7 & 18.8 & 16.9 & 22.8 \\
\hline Government & 1.4 & 2.2 & 3.9 & 6.2 & 6.2 & 4.7 & 9.3 \\
\hline Nongovernment & 6.6 & 11.2 & 11.4 & 12.6 & 12.6 & 12.1 & 13.5 \\
\hline \multicolumn{8}{|l|}{ Central government operations 3/ } \\
\hline Total revenue & 10.7 & 11.9 & 16.2 & 20.0 & 21.4 & 22.4 & 26.5 \\
\hline Total expenditure & 11.6 & 12.7 & 15.5 & 18.4 & 22.0 & 23.0 & 25.4 \\
\hline Overall balance (cash) & -0.9 & -0.8 & 0.7 & 1.5 & -0.6 & -0.6 & 1.1 \\
\hline \multicolumn{8}{|l|}{ Money and credit } \\
\hline Broad money (change in percent) & 24.7 & 30.3 & 30.3 & 30.8 & 28.0 & 33.0 & 28.0 \\
\hline Reserve money (change in percent) & 3.7 & 22.0 & 26.6 & 27.8 & 29.1 & 29.9 & 24.6 \\
\hline Velocity (non-oil nominal GDP over average broad money) & 8.1 & 7.1 & 6.5 & 5.7 & 5.2 & 4.9 & 4.6 \\
\hline & \multicolumn{7}{|c|}{ (In millions of U.S. dollars; unless otherwise indicated) } \\
\hline \multicolumn{8}{|l|}{ External sector } \\
\hline Exports, f.o.b. & 1,699 & 1,949 & 2,577 & 3,778 & 4,975 & 5,619 & 9,550 \\
\hline Of which: Oil & 1,377 & 1,511 & 2,082 & 3,101 & 4,220 & 4,915 & 8,776 \\
\hline Imports, f.o.b. & 2,031 & 2,153 & 2,536 & 3,586 & 4,712 & 5,122 & 6,785 \\
\hline Non-oil export volume (change in percent) & -25.4 & 43.8 & -8.5 & 9.6 & 7.1 & 1.1 & 8.6 \\
\hline Non-oil import volume (change in percent) & 30.8 & 5.2 & 6.7 & 32.8 & 30.8 & 34.5 & 32.4 \\
\hline Current account balance on cash basis & $-1,289$ & -918 & -827 & -816 & $-1,409$ & $-1,404$ & -372 \\
\hline In percent of GDP & -9.6 & -6.1 & -4.7 & -3.8 & -5.6 & -5.0 & -1.0 \\
\hline Terms of trade (Index $1993=100$, change in percent) & -7.9 & -2.4 & 7.9 & 20.0 & -4.0 & 27.6 & 3.6 \\
\hline Nominal effective exchange rate (change in percent) $4 / 5$ / & 3.5 & -6.7 & -9.7 & -2.9 & $\ldots$ & 8.2 & 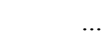 \\
\hline Real effective exchange rate (change in percent) $4 / 5 /$ & 7.9 & -1.9 & -4.9 & 1.2 & $\ldots$ & 17.5 & \\
\hline External debt (in billions of U.S. dollars) & 20.9 & 23.6 & 25.7 & 26.0 & 26.5 & 27.0 & 28.6 \\
\hline External debt (percent of GDP) & 156.8 & 156.8 & 146.5 & 121.1 & 110.9 & 96.1 & 71.5 \\
\hline Debt service ratio (commitment basis) 6/ & 38.4 & 37.5 & 31.6 & 23.2 & 16.0 & 16.8 & 9.5 \\
\hline Debt service ratio (actual payments basis) 6/ & 5.1 & 6.8 & 9.5 & 7.9 & 5.2 & 5.8 & 3.6 \\
\hline Gross usable reserves (in millions of U.S. dollars) 4/ & 45 & 249 & 527 & 1,338 & 1,754 & 2,005 & 3,392 \\
\hline In months of next year's imports & 0.2 & 1.0 & 1.5 & 2.5 & 3.2 & 2.9 & 4.1 \\
\hline Sudan's crude-oil export price (U.S. dollars per barrel) & 22.0 & 23.0 & 27.0 & 36.4 & 34.0 & 51.8 & 54.7 \\
\hline
\end{tabular}

Sources: Sudanese authorities; and Fund staff estimates and projections.

1/ GDP-related figures are expressed at market prices (the original program displayed GDP at factor cost).

2/ Projections based on August 2005 WEO oil prices.

3/ Cash basis.

4/ End of period.

5/ For 2005, the data reflect the change up to August.

6/ As a share of exports of goods and services. 
Table 2. Sudan: Central Government Operations 2003-05

\begin{tabular}{|c|c|c|c|c|c|c|}
\hline & \multirow[t]{2}{*}{2003} & \multirow[t]{2}{*}{2004} & \multicolumn{4}{|c|}{2005} \\
\hline & & & \multicolumn{2}{|c|}{ Jan-Jun } & \multicolumn{2}{|c|}{ Year } \\
\hline & Act. & Act. & Prog. & Est. & Prog. & Rev. Prog. \\
\hline & \multicolumn{6}{|c|}{ (In billions of Sudanese dinars) } \\
\hline Total revenues & 741.9 & $1,104.5$ & 603.1 & 679.2 & $1,348.3$ & $1,545.9$ \\
\hline Tax revenue & 270.0 & 420.5 & 217.8 & 228.7 & 467.4 & 490.0 \\
\hline Direct taxes & 52.3 & 74.7 & 42.2 & 48.1 & 95.0 & 99.0 \\
\hline Indirect taxes & 217.7 & 345.8 & 175.6 & 180.6 & 372.4 & 391.0 \\
\hline Nontax revenues & 471.9 & 684.0 & 385.3 & 450.5 & 880.9 & $1,055.9$ \\
\hline Departmental fees & 10.7 & 14.1 & 8.0 & 6.5 & 18.6 & 17.8 \\
\hline National revenues & 461.2 & 669.9 & 377.4 & 444.0 & 862.3 & $1,038.1$ \\
\hline Non-oil & 38.7 & 90.6 & 40.3 & 41.3 & 83.0 & 89.9 \\
\hline Oil 1/ & 422.6 & 579.3 & 337.0 & 402.7 & 779.3 & 948.2 \\
\hline Total expenditures & 708.4 & $1,019.5$ & 616.7 & 681.0 & $1,386.9$ & $1,587.3$ \\
\hline Current expenditures & 563.8 & 762.5 & 522.7 & 575.3 & $1,169.0$ & $1,374.2$ \\
\hline Chapter One (Wages and salaries) & 191.1 & 273.8 & 129.4 & 145.7 & 301.0 & 309.0 \\
\hline Chapter Two (Other current spending) & 321.3 & 404.6 & 170.9 & 296.9 & 368.6 & 639.6 \\
\hline Debt service paid & 73.0 & 81.1 & 37.6 & 38.9 & 70.0 & 85.9 \\
\hline Goods and services & 54.5 & 71.0 & 45.0 & 33.6 & 101.0 & 90.1 \\
\hline General reserves & 104.0 & 144.3 & 37.8 & 82.8 & 90.0 & 155.0 \\
\hline Other & 89.8 & 108.1 & 50.5 & 141.6 & 107.6 & 308.7 \\
\hline Of which: Implicit fuel subsidy $1 /$ & $\ldots$ & $\ldots$ & 0.0 & 96.0 & 0.0 & 200.5 \\
\hline Chapter three (Transfers to subnational governments) & 51.4 & 84.2 & 222.3 & 132.8 & 499.4 & 425.6 \\
\hline Capital expenditures & 135.2 & 277.2 & 94.0 & 109.2 & 217.9 & 217.7 \\
\hline Locally financed & 112.8 & 227.5 & 63.0 & 87.7 & 134.7 & 160.8 \\
\hline Foreign financed & 22.4 & 49.7 & 31.0 & 21.5 & 83.2 & 56.9 \\
\hline Discrepancy & 9.3 & -20.2 & 0.0 & -3.5 & 0.0 & -4.5 \\
\hline Overall balance (deficit -) & 33.5 & 85.0 & -13.6 & -1.9 & -38.6 & -41.4 \\
\hline Financing & -33.5 & -85.0 & 13.6 & 1.9 & 38.6 & 41.4 \\
\hline Foreign financing & -15.2 & 5.2 & 20.0 & 3.7 & 57.0 & 12.1 \\
\hline Domestic financing & -18.3 & -90.2 & -6.4 & -1.9 & -18.4 & 29.4 \\
\hline Central bank & -31.9 & -85.9 & -29.1 & 1.4 & -62.5 & -11.5 \\
\hline Commercial banks & 12.8 & 6.7 & 17.5 & 5.0 & 35.0 & 29.0 \\
\hline Non-banks & 28.7 & 22.9 & 6.3 & 29.2 & 14.7 & 49.9 \\
\hline Domestic arrears repayment (-) & -30.0 & -33.9 & -7.8 & -34.2 & -15.3 & -48.1 \\
\hline Privatization & 2.1 & 0.0 & 6.8 & -3.3 & 9.7 & 10.0 \\
\hline
\end{tabular}


Table 2. Sudan: Central Government Operations 2003-05 (Concluded)

\begin{tabular}{|c|c|c|c|c|c|c|}
\hline & 2003 & 2004 & \multicolumn{4}{|c|}{2005} \\
\hline & & & \multicolumn{2}{|c|}{ Jan-Jun } & \multicolumn{2}{|c|}{ Year } \\
\hline & Act. & Act. & Prog. & Est. & Prog. & Rev. Prog. \\
\hline & \multicolumn{6}{|c|}{ (In percent of GDP) } \\
\hline Total revenues & 16.2 & 20.0 & 9.6 & 9.8 & 21.4 & 22.4 \\
\hline Tax revenue & 5.9 & 7.6 & 3.5 & 3.3 & 7.4 & 7.1 \\
\hline Direct taxes & 1.1 & 1.3 & 0.7 & 0.7 & 1.5 & 1.4 \\
\hline Indirect taxes & 4.8 & 6.2 & 2.8 & 2.6 & 5.9 & 5.7 \\
\hline Nontax revenues & 10.3 & 12.4 & 6.1 & 6.5 & 14.0 & 15.3 \\
\hline Departmental fees & 0.2 & 0.3 & 0.1 & 0.1 & 0.3 & 0.3 \\
\hline National revenues & 10.1 & 12.1 & 6.0 & 6.4 & 13.7 & 15.0 \\
\hline Non-oil & 0.8 & 1.6 & 0.6 & 0.6 & 1.3 & 1.3 \\
\hline Oil 1/ & 9.2 & 10.5 & 5.4 & 5.8 & 12.4 & 13.7 \\
\hline Total expenditures & 15.5 & 18.4 & 9.8 & 9.9 & 22.0 & 23.0 \\
\hline Current expenditures & 12.3 & 13.8 & 8.3 & 8.3 & 18.6 & 19.9 \\
\hline Chapter One (Wages and salaries) & 4.2 & 4.9 & 2.1 & 2.1 & 4.8 & 4.5 \\
\hline Chapter Two (Other current spending) & 7.0 & 7.3 & 2.7 & 4.3 & 5.9 & 9.3 \\
\hline Debt service paid & 1.6 & 1.5 & 0.6 & 0.6 & 1.1 & 1.2 \\
\hline Goods and services & 1.2 & 1.3 & 0.7 & 0.5 & 1.6 & 1.3 \\
\hline General reserves & 2.3 & 2.6 & 0.6 & 1.2 & 1.4 & 2.2 \\
\hline Other & 2.0 & 2.0 & 0.8 & 2.0 & 1.7 & 4.5 \\
\hline Of which: Implicit fuel subsidy 1/ & $\ldots$ & $\ldots$ & 0.0 & 1.4 & 0.0 & 2.9 \\
\hline Chapter three (Transfers to subnational governments) & 1.1 & 1.5 & 3.5 & 1.9 & 7.9 & 6.2 \\
\hline Capital expenditures & 3.0 & 5.0 & 1.5 & 1.6 & 3.5 & 3.1 \\
\hline Locally financed & 2.5 & 4.1 & 1.0 & 1.3 & 2.1 & 2.3 \\
\hline Foreign financed & 0.5 & 0.9 & 0.5 & 0.3 & 1.3 & 0.8 \\
\hline Discrepancy & 0.2 & -0.4 & 0.0 & -0.1 & 0.0 & -0.1 \\
\hline Overall balance (deficit -) & 0.7 & 1.5 & -0.2 & 0.0 & -0.6 & -0.6 \\
\hline Financing & -0.7 & -1.5 & 0.2 & 0.0 & 0.6 & 0.6 \\
\hline Foreign financing & -0.3 & 0.1 & 0.3 & 0.1 & 0.9 & 0.2 \\
\hline Domestic financing & -0.4 & -1.6 & -0.1 & 0.0 & -0.3 & 0.4 \\
\hline Central bank & -0.7 & -1.6 & -0.5 & 0.0 & -1.0 & -0.2 \\
\hline Commercial banks & 0.3 & 0.1 & 0.3 & 0.1 & 0.6 & 0.4 \\
\hline Non-banks & 0.6 & 0.4 & 0.1 & 0.4 & 0.2 & 0.7 \\
\hline Domestic arrears repayment (-) & -0.7 & -0.6 & -0.1 & -0.5 & -0.2 & -0.7 \\
\hline Privatization & 0.0 & 0.0 & 0.1 & 0.0 & 0.2 & 0.1 \\
\hline \multicolumn{7}{|l|}{ Memorandum items } \\
\hline Non-oil revenue 2 / & 8.4 & 10.9 & 4.8 & 4.8 & 10.3 & 10.4 \\
\hline \multicolumn{7}{|l|}{ Consolidated expenditures 3 / } \\
\hline Current & 12.5 & 13.4 & 7.5 & 7.7 & 16.3 & 18.1 \\
\hline Capital & 3.0 & 5.0 & 2.3 & 2.1 & 5.7 & 4.9 \\
\hline Non-oil domestic balance (primary) & -4.7 & -5.7 & -4.4 & -4.8 & -9.4 & -12.3 \\
\hline Nominal GDP (in billions of Sudanese dinars) & 4,580 & 5,535 & 6,299 & 6,912 & 6,299 & 6,912 \\
\hline
\end{tabular}

Sources: Sudanese authorities; and Fund staff estimates and projections.

1/ Oil revenues are valued on an accrual basis and the shortfall from the low consumer prices is accounted explicitly as a subsidy within Chapter Two expenditures. The subsidy is on both imported and domestically-produced oil products.

2 / In percent of non-oil GDP. The reduction in the ratio in 2005 reflects a drop in excise rates.

3 / Includes estimated capital spending by subnational governments. It is assumed that part of the transfers to subnational governments in Chapter 3 above is utilized as capital spending. 
Table 3. Sudan: Monetary Survey, 2003-05

\begin{tabular}{|c|c|c|c|c|c|c|c|}
\hline & \multirow{2}{*}{$\begin{array}{r}2003 \\
\text { Dec. } \\
\text { Actual }\end{array}$} & \multirow{2}{*}{$\begin{array}{r}2004 \\
\text { Dec. } \\
\text { Actual }\end{array}$} & \multicolumn{5}{|c|}{2005} \\
\hline & & & $\begin{array}{l}\text { June } \\
\text { Prog. }\end{array}$ & $\begin{array}{r}\text { June } \\
\text { Actual }\end{array}$ & $\begin{array}{r}\text { Sept. } \\
\text { Est. }\end{array}$ & $\begin{array}{l}\text { Dec. } \\
\text { Prog. }\end{array}$ & $\begin{array}{r}\text { Dec. } \\
\text { Rev. Prog. }\end{array}$ \\
\hline & \multicolumn{7}{|c|}{ (In billions of Sudanese dinars, unless otherwise indicated) } \\
\hline Net foreign assets & -570.0 & -341.7 & -279.5 & -148.7 & -104.0 & -202.4 & -76.5 \\
\hline Bank of Sudan & -685.4 & -464.8 & -411.5 & -325.8 & -268.2 & -346.5 & -246.5 \\
\hline Commercial banks & 115.5 & 123.1 & 132.1 & 177.1 & 164.2 & 144.1 & 170.1 \\
\hline Counterpart to valuation changes 1 / & 817.0 & 791.6 & 789.1 & 783.7 & 756.2 & 787.6 & 721.6 \\
\hline Net foreign assets (excluding valuation adjustment) & 247.1 & 449.9 & 508.8 & 634.9 & 652.1 & 584.4 & 645.1 \\
\hline Net domestic assets & 487.0 & 510.5 & 579.3 & 546.2 & 563.3 & 643.7 & 632.3 \\
\hline Net domestic credit & 423.8 & 484.4 & 495.3 & 607.7 & 600.9 & 584.9 & 687.5 \\
\hline Net claims on general government & 140.3 & 67.8 & 73.6 & 37.8 & 36.5 & 72.9 & 50.0 \\
\hline Bank of Sudan claims on central government & 111.7 & 32.5 & 21.6 & -1.4 & 2.3 & 4.0 & -14.3 \\
\hline Bank of Sudan claims on state governments & 0.0 & 0.0 & 0.0 & -1.1 & -22.6 & 0.0 & 0.0 \\
\hline Commercial banks & 28.6 & 35.3 & 52.0 & 40.3 & 56.8 & 68.9 & 64.3 \\
\hline Claims on nongovernment sectors & 312.1 & 451.9 & 473.7 & 569.9 & 564.4 & 580.9 & 637.5 \\
\hline Other items (net) & 63.2 & 26.2 & 84.1 & -61.5 & -37.7 & 59.8 & -55.2 \\
\hline Broad money & 734.1 & 960.4 & $1,088.5$ & $1,180.0$ & $1,215.4$ & $1,229.4$ & $1,277.4$ \\
\hline Currency outside banks & 240.2 & 304.9 & 359.2 & 324.7 & 333.5 & 405.7 & 347.5 \\
\hline Deposits & 493.9 & 655.5 & 729.3 & 855.3 & 881.9 & 823.7 & 929.9 \\
\hline \multicolumn{8}{|l|}{ Memorandum items: } \\
\hline Reserve money (annual percentage change) & 26.6 & 27.8 & 32.9 & 40.0 & 32.0 & 29.1 & 29.9 \\
\hline Broad money (annual percentage change) & 30.3 & 30.8 & 29.7 & 40.6 & 38.0 & 28.0 & 33.0 \\
\hline Credit to nongovernment sector (annual percentage change) & 56.9 & 44.8 & 24.6 & 50.0 & 45.4 & 28.5 & 41.1 \\
\hline Currency to broad money (in percent) & 32.7 & 31.7 & 33.0 & 27.5 & 27.4 & 33.0 & 27.2 \\
\hline Foreign currency deposits to total deposits (in percent) & 37.2 & 37.7 & 39.3 & 36.5 & 35.3 & 39.3 & 35.3 \\
\hline Broad money multiplier & 2.1 & 2.1 & 2.1 & 2.2 & 2.2 & 2.1 & 2.2 \\
\hline Non-oil GDP velocity (average) & 6.5 & 5.7 & $\ldots$ & $\ldots$ & $\ldots$ & 5.2 & 4.9 \\
\hline Usable international reserves to broad money (in percent) & 18.7 & 35.0 & 36.8 & 32.3 & 37.2 & 35.7 & 36.1 \\
\hline Commercial banks credit to the government (cumulative change) & 12.8 & 6.7 & 16.7 & 5.0 & 21.5 & 35.0 & 29.0 \\
\hline
\end{tabular}

Sources: Sudanese authorities; and Fund staff estimates.

1/ The figures for 2005 are calculated at the program exchange rate. 
Table 4. Sudan: Monetary Authorities’ Accounts, 2003-05

\begin{tabular}{|c|c|c|c|c|c|c|c|}
\hline & \multirow{2}{*}{$\begin{array}{r}2003 \\
\text { Dec } \\
\text { Actual }\end{array}$} & \multirow{2}{*}{ 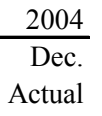 } & \multicolumn{5}{|c|}{2005} \\
\hline & & & $\begin{array}{l}\text { June } \\
\text { Prog. }\end{array}$ & $\begin{array}{r}\text { June } \\
\text { Actual }\end{array}$ & $\begin{array}{r}\text { Sept. } \\
\text { Est. }\end{array}$ & $\begin{array}{l}\text { Dec. } \\
\text { Prog. }\end{array}$ & $\begin{array}{r}\text { Dec. } \\
\text { Rev. Prog. }\end{array}$ \\
\hline & \multicolumn{7}{|c|}{ (In billions of Sudanese dinars) } \\
\hline Net foreign assets & -685.4 & -464.8 & -411.5 & -325.8 & -268.2 & -346.5 & -246.5 \\
\hline Foreign assets & 229.7 & 420.4 & 469.2 & 526.1 & 570.7 & 529.2 & 573.8 \\
\hline Foreign liabilities & 915.2 & 885.1 & 880.7 & 852.0 & 838.9 & 875.7 & 820.3 \\
\hline Counterpart to valuation changes 1 / & 816.6 & 788.6 & 788.5 & 778.4 & 750.6 & 788.1 & 715.1 \\
\hline Net domestic assets & 223.7 & 129.5 & 141.3 & 95.4 & 63.5 & 143.8 & 120.1 \\
\hline Net domestic credit & 131.2 & 42.6 & 25.7 & 46.9 & 31.9 & 13.8 & 44.9 \\
\hline Net claims on central government & 83.1 & -2.8 & -31.4 & -1.4 & 2.3 & -64.9 & -14.3 \\
\hline Claims & 147.9 & 148.7 & 152.3 & 174.9 & 152.3 & 158.7 & 150.6 \\
\hline Deposits 2/ & 64.8 & 151.5 & 183.7 & 176.3 & 150.0 & 223.6 & 164.9 \\
\hline Of which: new oil savings account 3 / & $\ldots$ & $\ldots$ & 32.7 & 76.6 & 99.9 & 72.6 & 135.0 \\
\hline Net claims on state governments & $\ldots$ & .... & $\ldots$ & -1.1 & -22.6 & $\ldots$ & 0.0 \\
\hline Claims on public enterprises & 17.3 & 15.5 & 17.5 & 18.1 & 22.2 & 17.5 & 22.2 \\
\hline Claims on banks & 33.5 & 30.0 & 39.5 & 31.3 & 30.0 & 61.2 & 42.0 \\
\hline Money market instruments & 0.0 & 0.0 & 0.0 & 0.0 & 0.0 & 0.0 & -5.0 \\
\hline Other items (net) & 92.5 & 86.9 & 115.2 & 48.5 & 31.6 & 130.0 & 75.2 \\
\hline Reserve money & 354.8 & 453.3 & 518.3 & 545.8 & 545.9 & 585.4 & 588.7 \\
\hline Currency outside banks & 240.2 & 304.9 & 359.2 & 324.7 & 333.5 & 405.7 & 347.5 \\
\hline Reserves of commercial banks & 87.2 & 128.2 & 136.1 & 187.1 & 183.2 & 156.7 & 197.2 \\
\hline Required reserves & 42.5 & 57.5 & 62.7 & 75.9 & 73.9 & 70.8 & 82.8 \\
\hline Excess reserves & 44.7 & 70.7 & 73.4 & 111.1 & 109.3 & 85.9 & 114.4 \\
\hline Deposits at Bank of Sudan included in broad money & 27.4 & 20.2 & 23.0 & 34.0 & 29.2 & 23.0 & 44.0 \\
\hline Memorandum items: & & & & & & & \\
\hline Credit to the government (cumulative change) & -31.9 & -85.9 & -28.5 & 1.4 & 5.1 & -62.5 & -11.5 \\
\hline
\end{tabular}

Sources: Sudanese authorities; and Fund staff estimates.

$1 /$ The figures for 2005 are calculated at the program exchange rate.

2/ Includes proceeds from the old oil savings account, which had a balance of SDD 129 billion at end-2004. In 2005, these balances remain as government deposits and will be used for budget financing.

3/ Balance of the new oil savings account of the national unity government (as envisaged in the peace agreement with the south). 
Table 5. Sudan: Balance of Payments, 2003-05

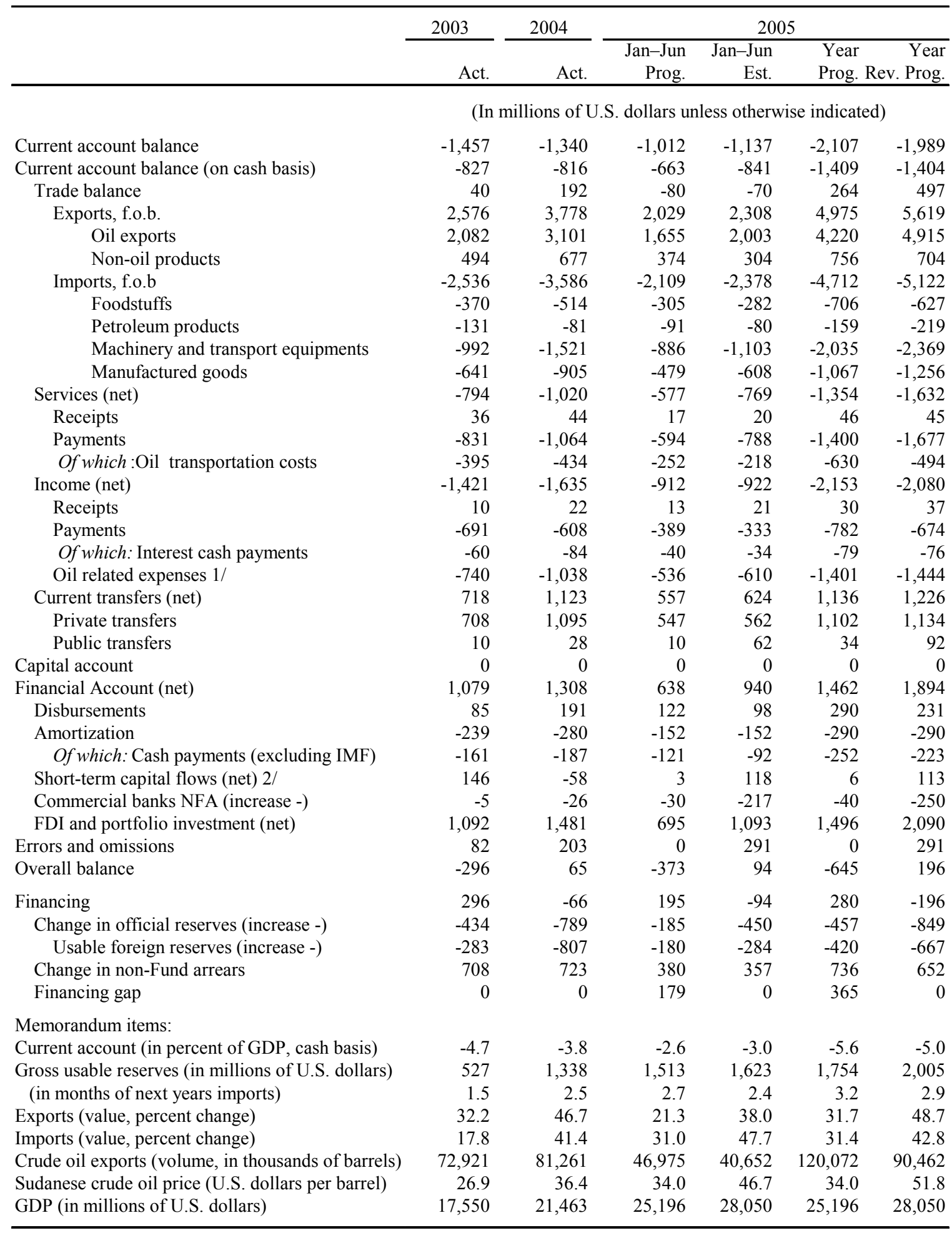

Source: Staff estimates based on information provided by the Sudanese authorities.

1/ Includes payments to oil companies related to profit-sharing arrangements.

2/ Net short-term trade and other credit facilities of the government and commercial banks. 
Table 6. Sudan: Quantitative Targets Under the Staff-Monitored Program

\begin{tabular}{|c|c|c|c|c|c|c|}
\hline & \multirow{3}{*}{$\frac{20041 /}{\text { Dec. }}$} & \multicolumn{5}{|c|}{ Cumulative Change During 2005} \\
\hline & & \multicolumn{3}{|c|}{ Jan.-June } & \multicolumn{2}{|c|}{ Jan.-Dec. } \\
\hline & & $\begin{array}{l}\text { Mid-year } \\
\text { Program }\end{array}$ & $\begin{array}{r}\text { Program } \\
\text { w/adjustor } 2 /\end{array}$ & Actual & $\begin{array}{l}\text { End-year } \\
\text { Program }\end{array}$ & $\begin{array}{r}\text { End-year } \\
\text { Rev. Prog. }\end{array}$ \\
\hline & \multicolumn{6}{|c|}{ (In billions of Sudanese dinars; unless otherwise indicated) } \\
\hline Bank of Sudan net domestic assets & 129.5 & 11.8 & -32.1 & -34.1 & 14.3 & -34.2 \\
\hline Domestic financing of the central government 3 / & -100.4 & -6.3 & -51.2 & -1.9 & -17.5 & 29.4 \\
\hline $\begin{array}{l}\text { Contracting or guaranteeing of external nonconcessional debt } \\
\text { by the government or the central bank (in millions of U.S. dollars) } 4 \text { / }\end{array}$ & 310 & & .. & 803 & 150 & 803 \\
\hline Gross official usable reserves (in millions of U.S. dollars) 5/ & 1,338 & 180 & 358 & 284 & 420 & 667 \\
\hline Payments to the Fund (in millions of U.S. dollars) & 32.4 & 15.0 & $\cdots$ & 16.5 & 30.0 & 30.0 \\
\hline \multicolumn{7}{|l|}{ Memorandum items: } \\
\hline Broad money & 960.4 & 128.0 & $\ldots$ & 219.6 & 268.9 & 316.9 \\
\hline Oil savings account & 129.0 & 32.7 & $\ldots$ & 76.6 & 72.6 & 135.0 \\
\hline
\end{tabular}

Sources: Sudanese authorities; and Fund staff estimates.

1/ Outstanding stock at end-2004.

2/ The four midyear targets were: i) Ceiling on BOS NDA; ii) ceiling on domestic finincing of central government; iii) floor on growth of official reserves; and iv) floor on payments to the IMF.

3/ Defined as total net borrowing by the government, including net borrowing from the central bank (including Government Musharaka Certificates (GMCs) and changes in deposits of the central government with the central bank but excluding oil savings account), net sales of GMCs outside the central bank, revenues from privatization, and repayments of domestic arrears.

4/ This target applies not only to debt as defined in point No. 9 of the Guidelines on Performance Criteria with Respect to Foreign Debt

(Decision No. 12274 - (00/85), August 24, 2000), but also to commitments contracted or guaranteed for which value has not been received.

Debt will be deemed to be concessional when the currency-specific discount rate (determined by the market-related "commercial interest reference rates

(CIRR)" as published by the OECD) applied to the contractual schedule of charges and principal payments indicates a grant element of at least 35 percent

The target excludes the financing of the Merowe hydropower project. The end-December target in the revised program has been increased

to reflect a higher-than-programmed oil price.

5 / Including foreign banknotes in the vaults of the central bank. 
Table 7. Sudan: Structural Benchmarks Under the Staff-Monitored Program

\begin{tabular}{|c|c|}
\hline Measures & $\begin{array}{c}\text { Status as of } \\
\text { end-October } 2005\end{array}$ \\
\hline \multicolumn{2}{|l|}{ By end-June 2005} \\
\hline $\begin{array}{l}\text { 1. Introduce an auction system with competitive selling price for the } \\
\text { General Musharaka Certificates (GMC) and General Investment } \\
\text { Certificates (GIC) securities in the primary market. }\end{array}$ & Met \\
\hline $\begin{array}{l}\text { 2. Set up and operationalize a single treasury account for all Ministry } \\
\text { of Finance operations. }\end{array}$ & Met \\
\hline 3. Establish a medium-size taxpayers' unit. & Met \\
\hline $\begin{array}{l}\text { 4. Develop a program (including timetable) for aligning the SPC and } \\
\text { its subsidiaries' accounting systems with commercial standards by } \\
\text { end-2006. }\end{array}$ & Met \\
\hline \multicolumn{2}{|l|}{ By end-December 2005} \\
\hline 5. Formulate the 2006 budget based on GFS classification. & In progress \\
\hline $\begin{array}{l}\text { 6. Prepare a three-year import-tariff reform program and incorporate it } \\
\text { in the } 2006 \text { budget. }\end{array}$ & In progress \\
\hline $\begin{array}{l}\text { 7. Establish a new financing window that allows liquidity constrained } \\
\text { banks to sell securities to the central bank at a penalty rate. }\end{array}$ & Met \\
\hline $\begin{array}{l}\text { 8. Prepare a financial sector reform program in light of FSAP } \\
\text { recommendations. }\end{array}$ & Met \\
\hline
\end{tabular}


Table 8. Sudan: Medium-Term Macroeconomic Scenario, 2004-10

\begin{tabular}{|c|c|c|c|c|c|c|c|}
\hline & 2004 & 2005 & 2006 & 2007 & 2008 & 2009 & 2010 \\
\hline & Actual & \multicolumn{6}{|c|}{ Projections } \\
\hline & \multicolumn{7}{|c|}{ (Change in percent, unless otherwise indicated) } \\
\hline \multicolumn{8}{|l|}{ Production and prices } \\
\hline Nominal GDP (in millions of U.S. dollars) & 21,463 & 28,050 & 37,261 & 42,549 & 47,347 & 52,184 & 57,176 \\
\hline Real GDP & 5.2 & 8.2 & 13.4 & 8.8 & 8.7 & 8.1 & 7.5 \\
\hline Oil & 9.9 & 8.2 & 63.6 & 13.7 & 10.3 & 5.1 & 4.1 \\
\hline Non-oil & 4.8 & 8.2 & 7.8 & 7.9 & 8.4 & 8.6 & 8.1 \\
\hline Inflation (period average) & 8.4 & 10.5 & 7.0 & 5.0 & 4.0 & 3.0 & 3.0 \\
\hline & \multicolumn{7}{|c|}{ (In percent of GDP, unless otherwise indicated) } \\
\hline \multicolumn{8}{|l|}{ Investment and saving } \\
\hline Gross investment & 22.5 & 21.9 & 25.3 & 26.0 & 26.8 & 27.5 & 27.1 \\
\hline Government 1/ & 5.0 & 4.9 & 8.1 & 8.6 & 8.8 & 8.9 & 8.5 \\
\hline Nongovernment & 17.5 & 17.0 & 17.2 & 17.4 & 18.0 & 18.6 & 18.6 \\
\hline Gross national saving & 18.7 & 16.9 & 24.3 & 22.7 & 23.2 & 21.7 & 21.6 \\
\hline Government & 6.2 & 4.7 & 9.3 & 10.1 & 9.0 & 8.9 & 8.4 \\
\hline Nongovernment & 12.6 & 12.1 & 15.0 & 12.5 & 14.2 & 12.8 & 13.2 \\
\hline \multicolumn{8}{|l|}{ Central government } \\
\hline Total revenue & 20.0 & 22.4 & 26.5 & 28.2 & 28.2 & 27.9 & 27.8 \\
\hline Of which: Oil revenue 2/ & 10.4 & 13.7 & 18.2 & 19.8 & 19.1 & 18.3 & 17.6 \\
\hline Total expenditure & 18.8 & 23.1 & 25.3 & 26.6 & 27.9 & 28.1 & 27.9 \\
\hline Current expenditures & 13.8 & 18.1 & 17.0 & 18.1 & 19.1 & 19.1 & 19.4 \\
\hline Capital expenditure & 5.0 & 5.0 & 8.3 & 8.6 & 8.8 & 8.9 & 8.5 \\
\hline Overall balance (cash basis) & 1.2 & -0.7 & 1.2 & 1.6 & 0.2 & -0.1 & -0.2 \\
\hline \multicolumn{8}{|l|}{ External sector } \\
\hline External trade balance & 0.9 & 1.8 & 7.4 & 4.7 & 3.7 & 2.9 & 2.4 \\
\hline Exports & 17.6 & 20.0 & 25.6 & 24.6 & 23.6 & 22.0 & 21.0 \\
\hline Imports & 16.7 & 18.3 & 18.2 & 19.8 & 20.0 & 19.0 & 18.6 \\
\hline Current account balance on cash basis & -3.8 & -5.0 & -1.0 & -3.3 & -3.6 & -5.2 & -5.2 \\
\hline Gross official reserves (in months of imports) & 2.5 & 2.9 & 4.1 & 4.4 & 4.8 & 4.9 & 5.0 \\
\hline Non-oil export volume (change in percent) & 9.6 & 1.1 & 8.6 & 9.0 & 10.0 & 10.6 & 11.5 \\
\hline Non-oil import volume (change in percent) & 32.8 & 34.5 & 32.4 & 24.8 & 11.4 & 4.7 & 5.2 \\
\hline Terms of trade (change in percent) & 20.0 & 27.6 & 3.6 & 0.4 & -4.1 & -1.4 & -2.3 \\
\hline \multicolumn{8}{|l|}{ Memorandum item: } \\
\hline Crude oil export price (U.S. dollars per barrel) 3/ & 36.4 & 51.8 & 54.7 & 55.3 & 53.3 & 52.7 & 51.9 \\
\hline
\end{tabular}

Sources: Sudanese authorities; and Fund staff estimates and projections.

$1 /$ Includes estimated capital spending by state governments.

2/ Crude oil revenue.

3/ Projections based on August 2005 WEO oil prices 


\section{RELATIONS With THE FUND}

(As of September 30, 2005)

I. Membership Status: Joined 09/05/57; Article VIII.

II. General Resources Account:

Quota

Fund holdings of currency

Reserve position in Fund

III. SDR Department:

Net cumulative allocation

Holdings

\begin{tabular}{l} 
SDR Million \\
\hline 169.70 \\
476.95 \\
0.01 \\
SDR Million \\
52.19 \\
0.40
\end{tabular}

0.40

$$
\begin{array}{r}
\% \text { Quota } \\
\hline 100.00 \\
281.05 \\
0.01
\end{array}
$$

$\%$ Allocation

100.00

0.77

IV. Outstanding Purchases and Loans: $\underline{\text { SDR Million }}$

Stand-by Arrangements

179.62

Extended Arrangements

108.05

105.85

63.67

Contingency and Compensatory

Financing Facility

19.55

Trust fund

59.23

\begin{tabular}{|c|c|c|c|c|}
\hline Type & $\begin{array}{c}\text { Approval } \\
\text { Date }\end{array}$ & Expiration Date & $\begin{array}{c}\text { Amount } \\
\text { Approved } \\
\text { (SDR million) }\end{array}$ & 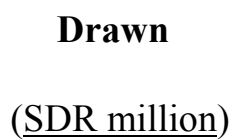 \\
\hline Stand-by & $06 / 25 / 1984$ & $06 / 24 / 1985$ & 90.00 & 20.00 \\
\hline Stand-by & $02 / 23 / 1983$ & 03/09/1984 & 170.00 & 170.00 \\
\hline Stand-by & $02 / 22 / 1982$ & $02 / 21 / 1983$ & 198.00 & 70.00 \\
\hline
\end{tabular}

11.52

34.90

V. Financial Arrangements:

\begin{tabular}{|c|c|c|c|c|c|c|}
\hline \multicolumn{7}{|c|}{ Overdue $^{18}$} \\
\hline & & 2005 & 2006 & 2007 & 2008 & 2009 \\
\hline Principal & 366.45 & & & & & \\
\hline Charges/Interest & $\underline{688.42}$ & $\underline{3.53}$ & $\underline{13.63}$ & $\underline{13.63}$ & $\underline{13.65}$ & 13.62 \\
\hline Total & $1,054.87$ & $\overline{3.53}$ & $\overline{13.63}$ & $\overline{13.63}$ & $\overline{13.65}$ & $\overline{13.62}$ \\
\hline
\end{tabular}

VI. Projected Obligations to the Fund: (SDR million; based on existing use of resources and present holdings of SDRs):

\footnotetext{
18 The projection of charges and interest assumes that overdue principal at the report date (if any) will remain outstanding, but forthcoming obligations will be settled on time.
} 


\section{VII.Exchange Rate Arrangements}

The legal tender is the Sudanese dinar, which replaced the Sudanese pound in proportion SDD 1=LSd 10 in 1999. Since October 1998, the exchange rate system has been unified-market participants trade freely within a unified regulatory framework. In 2001, the foreign exchange market came under pressure and the Bank of Sudan (BOS) introduced a formal band of \pm 1.5 percent (later broadened to 2 percent) around the official rate and began auctioning its foreign exchange within the band. In May 2003, the BOS adopted formally a managed-floating exchange rate regime. The formal exchange rate band was abandoned and the auction system was replaced with direct transactions in the interbank market. The BOS established an internal limit of \pm 2 percent in intraday trading in the average daily market rate. In 2004, the BOS changed the permissible intraday exchange rate fluctuation from \pm 2 percentage points to \pm 3 percentage points. Sudan maintains one inoperative bilateral payment agreement with Egypt and an inoperative payment clearing account with the former Soviet Union.

Sudan maintains two exchange measures subject to Fund jurisdiction, an exchange restriction arising from the prohibition for importers in arrears with valid import licenses from executing payments and transfers for import transactions, and a multiple currency practice arising from the use of the historic buying rate for the resale of export proceeds. The authorities have stated their commitment to remove these restrictions by end-November 2005.

\section{Article IV Consultation}

Sudan is on a 12-month consultation cycle. The last Article IV consultation discussion was completed by the Executive Board on April 29, 2005 (Country Report No. 05/180; June 2, 2005).

\section{FSAP Participation}

The FSAP mission was conducted during December 1-20, 2004. The Financial System Stability Assessment report was discussed by the Executive Board on April 29, 2005.

\section{Resident Representative}

The Fund's resident representative office in Khartoum was reopened in October 2005.

\section{Technical Assistance}

In January 1995, the Executive Board decided to resume Fund selective technical assistance (TA) to Sudan. The following table contains a summary of the technical assistance provided since 2002. 
Sudan: Technical Assistance from the Fund, 2002-2005

\begin{tabular}{|c|c|c|c|}
\hline Subject & Type of Mission & Timing & Counterpart \\
\hline \multicolumn{4}{|l|}{ Fiscal Affairs Department } \\
\hline Expenditure control and management & Short-term & $\begin{array}{l}\text { Periodic visits } \\
\text { January-September } 2002\end{array}$ & MOF \\
\hline $\begin{array}{l}\text { Reform of direct taxation and revenue } \\
\text { administration }\end{array}$ & Short-term & November 2002 and December 2003 & MOF \\
\hline Reform of direct taxes and investment incentives & Short-term & March 2003 & MOF \\
\hline Medium-term budgetary framework & Short-term & April 2003 & MOF \\
\hline Tax and customs administration & Short-term & September 2003 & MOF \\
\hline $\begin{array}{l}\text { Fiscal cash management and budget } \\
\text { classification }\end{array}$ & Short-term & February 2004 & MOF \\
\hline $\begin{array}{l}\text { Fiscal cash management and budget } \\
\text { classification (METAC) }\end{array}$ & Short-term & $\begin{array}{l}\text { May and September } 2004 \\
\text { June and October } 2005\end{array}$ & MOF \\
\hline Revenue administration assessment (METAC) & Short-term & February 2005 & MOF \\
\hline \multicolumn{4}{|l|}{ Monetary and Financial Department } \\
\hline Monetary management and banking supervision & Short-term & Periodic visits, January-August 2002 & Bank of Sudan (BOS) \\
\hline Banking supervision & Resident Advisor & May 2001-May 2003 & BOS \\
\hline Islamic compliant monetary instruments & Short-term & October 2002 & BOS \\
\hline $\begin{array}{l}\text { Monetary policy operations and introduction of } \\
\text { a commodities futures/forward market in the } \\
\text { agriculture sector }\end{array}$ & Short-term & December 2003 & BOS \\
\hline Monetary policy operations & Short-term & September 2004 & BOS \\
\hline Currency workshop & Short-term & February 2005 & BOS \\
\hline Assessment of circulating currencies in Sudan & Short-term & March 23-April 22005 & BOS \\
\hline Banking supervision (METAC) & Short-term & August 27-31 2005 & BOS \\
\hline Reorganization of the Bank of Sudan & Short-term & August 27-September 12005 & BOS \\
\hline \multicolumn{4}{|l|}{ Statistics Department } \\
\hline Monetary statistics & Short-term & $\begin{array}{l}\text { Periodic visits, January- } \\
\text { November } 2003\end{array}$ & BOS \\
\hline National accounts and CPI statistics & Short-term & $\begin{array}{l}\text { Periodic visits, March 2002- } \\
\text { February } 2003\end{array}$ & $\begin{array}{l}\text { Central Bureau of } \\
\text { Statistics (CBS) }\end{array}$ \\
\hline Balance of payments statistics & Short-term & July 2003 & BOS \\
\hline General data dissemination system (GDDS) & Short-term & July 2003 & CBS, MFE and BOS \\
\hline $\begin{array}{l}\text { Assessing Sudan's emerging technical } \\
\text { assistance needs in economic statistics (with } \\
\text { METAC) }\end{array}$ & Short-term & May 25-June 2, 2005 & CBS, MOF and BOS \\
\hline Government Finance Statistics & Short-term & October 2005 & MOF \\
\hline
\end{tabular}




\section{SUDAN: RELATIONS WITH THE WORLD BANK ${ }^{19}$}

(As of October 15, 2005)

The World Bank has no active lending portfolio in Sudan because of Sudan's default on its financial obligations to the Bank, which led to the suspension of disbursements in April 1993. As a result of discussions between the Bank and the Sudanese authorities on the need for Sudan to take steps toward normalizing its relations and establishing a track record with the Bank, the authorities started making "good faith" payments of US\$1 million per month to the Bank starting in July 1999. Monthly payments of an equivalent of US\$500,000 have been made since October 2002. The amount of payments has not been sufficient to prevent a continued accumulation of arrears, which stood at about US\$357 million as of September 30, 2005 (from US\$145 million at the end of 1999). Sudan's outstanding Bank debt, including arrears, is approximately US\$1.3 billion.

The Bank was mostly absent from Sudan between 1992 and 2002. In the 1970s and 1980s, the Bank was a major player in the reconstruction of Sudan, following the Addis Ababa peace agreement of 1972. As the prospects for peace with the south rose in 2003, the Bank formulated a strategy for reengaging with Sudan in the event of peace. This strategy, described in the Sudan Country Reengagement Note (CRN), was discussed by the Executive Board of Directors on July 10, 2003. Main areas of emphasis in the CRN are knowledge generation and sharing, capacity building to support policy reform, demonstration projects to improve delivery of social services, and resolution of the debt overhang. In addition to capacity building, the Bank, together with the Fund, provided technical resource persons for the discussions around wealth sharing in the peace talks.

Between January 2004 and March 2005, the Bank coled (with the UN) a Joint Assessment Mission (JAM), covering eight thematic sectors. ${ }^{20}$ IMF staff participated in a number of workshops and contributed specifically to the economic policy cluster. The JAM synthesis report: "Framework for Transition, Reconstruction and Poverty Eradication," was completed in March 2005. The Report outlines the reconstruction and development needs for Sudan over the next six years, as well as a Monitoring Framework that reflects policy reforms and commitments made by the government, which are needed to implement the Comprehensive Peace Agreement (CPA). The Report, presented at an April 2005 Donors' Conference in Oslo, raised US\$2.0 billion in pledges for 2005-2007.

To report on progress on policy commitments and to renew financial pledges, it has been agreed that a twice-yearly Sudan Consortium meeting would be held. During the Consortium, the government, as well as the Bank, the IMF, and the UN would report on

\footnotetext{
${ }^{19}$ Prepared by World Bank staff. For additional information, contact Ms. Jill Armstrong, Country Program Coordinator for Sudan, Tel. (202) 473-8471.

${ }^{20}$ The full report can be found on the web at: http://www.unsudanig.org/JAM.
} 
progress. The assessment made by the Bank and IMF would lay out the joint views of staff with respect to the credibility and implementation of the policies and programs, key constraints, and proposed next steps. It is expected that the IMF would focus on the macroframework and budget and on selected fiscal and financial sector issues. The first meeting of the SC is expected to take place in January 2006.

The Comprehensive Peace Agreement agreed between the government of Sudan and the Sudan People's Liberation Movement (SPLM) specified that two Multi-Donor Trust Funds (MDTFs) be established to facilitate the coordination of external donor financing of Sudan's reconstruction and development needs as laid out in the JAM. One fund would be for the new National Government (NG) for war-affected areas in the north and the transition zones, and one for the government of Southern Sudan (GoSS). The MDTFs would remain operational through the six years of the Interim Period. MDTF-financed activities would be within the context of a unified budget and a coherent public expenditure process. Approximately US\$500 million was pledged in Oslo toward to two Trust Funds. The World Bank is the Administrator for both MDTFs. The MDTFs are now effective and the first projects are being prepared.

As part of the JAM, a workshop with the government and the SPLM initiated work on a joint strategy for poverty eradication (PRSP). IMF staff also participated. During this workshop, the parties reached an agreement on a shared vision for poverty eradication, with an articulation of strategic objectives and associated operational implications. A joint concept note was developed that provides the foundation for a national Poverty Eradication Strategy. Based on this work, the interim PRSP is expected to be finalized by mid-2006.

To support capacity building and policy reform, a US\$4.5 million Low-Income Countries under Stress (LICUS) trust-fund grant for Sudan was approved in December 2004. The grant focuses on capacity building and institutional development of fiduciary and aid-management systems both in the North and in the South. The trust fund complements two ongoing Post Conflict Fund grants from the World Bank totaling US\$3.0 million.

The Bank also participated in two missions to Sudan in October and December 2004 as part of the joint IMF-World Bank Financial Sector Assessment Program.

The World Bank is also preparing a Public Expenditure Review (PER), with selected broad activities, which are distinct for the NG and the GoSS. The proposed approach is pragmatic in that a series of distinct activities are being designed to build joint understanding and ownership and to begin to address capacity building needs over the next two and a half years (through end-2007). IMF staff will participate in this work in the areas of their competence.

In addition to the above, World Bank staff are working at a technical level with the IMF and other multilateral creditors to explore options for clearance of arrears and debt relief. 


\section{SUDAN: STATISTICAL ISSUES}

Available economic data are sufficient for program monitoring purposes in Sudan. However, there are many areas where further improvements are needed, particularly in compiling national accounts, state budgetary data, and external trade and financial statistics. This appendix discusses outstanding statistical issues by sector.

As a participant in the Department for International Development (DFID) project for Anglophone African countries, Sudan has been receiving technical assistance in various statistical issues. DFID financed three Statistics Department (STA) missions in JuneJuly 2003 (monetary and financial statistics, balance of payments statistics, and the General Data Dissemination System (GDDS) metadata completion), contributing to Sudan's participation in the GDDS starting in August 2003. An anniversary letter was sent in August 2005 requesting the authorities to provide updates to the GDDS metadata. In early 2004, Sudan also received assistance for the initial stages of preparation of a strategic plan for the Central Bureau of Statistics (CBS). In May 2005, an STA/METAC mission assessed the technical assistance needs in macroeconomic statistics and identified emerging statistical priorities in the statistics-producing agencies.

\section{REAL SECTOR}

The compilation and dissemination of the monthly Consumer Price Index have been commendable in recent years. Monthly CPI data for the Khartoum area are provided shortly after the end of each month while the CPI including other states is provided with a threemonth lag.

The compilation of the national accounts is subject to delay. The national accounts statistics suffer from a lack of basic information for many sectors, including oil, livestock, horticulture, and most services. On the expenditure side, data are lacking on final consumption by households, investment, and changes in stocks. There are no national accounts or industrial production data at sub annual frequencies. Furthermore, the annual data are being reported with a lag of over three years. There is an urgent need to increase funding to the CBS and rebuild its capacity. Priorities include introducing the 1993 System of National Accounts, conducting a census of agricultural production, carrying out a household survey, producing poverty statistics, and improving coordination between the CBS, the Ministry of Finance and National Economy (MOFNE), the Ministry of Energy and Mining, and the Ministry of Agriculture and Livestock. A peripatetic real sector expert provided some assistance on national accounts, through to the end of 2003.

\section{FISCAL SECTOR}

Government finance statistics reported to MCD are broadly adequate for program monitoring, with the main revenue, expenditure, and financing items reported on a monthly basis with a lag of about one month. Financing items are consistent with the monetary 
accounts. The reported statistics are for the central government only, and do not include the states and publicly owned corporations. Data are submitted using an economic classification and, while the allocation of resources by MOFNE to the various ministries is reported, their actual expenditures are not. There is an urgent need to improve accounting and reporting procedures at the MOFNE, introduce the GFS classifications according to guidelines provided in Government Finance Statistics Manual (GFSM) 2001, and implement the technical assistance recommendations on GFS. Data reported for the Government Finance Statistics Yearbook are weak and cover only budgetary central government up to 1999. Monthly and quarterly fiscal data are not reported for the International Financial Statistics (IFS).

\section{Monetary Sector}

Sudan has received significant technical assistance to improve the collection, compilation, and dissemination of monetary and financial statistics. Following a joint MCD and STA mission in October 1992, six STA missions were undertaken between 1993 and 2003 to further the development and implementation of the long-term plan of action initiated by the 1992 mission. Consequently, the monetary statistics compiled by the Bank of Sudan (BOS) are broadly acceptable for monitoring purposes. However, there is a concern that the absence of some prior actions as suggested by the July 2003 monetary and financial statistics mission may hinder the progress of the efforts to compile the monetary and financial statistics based on international standards. For example, an STA staff visit to Khartoum during May 2005 found that the harmonization of plan of accounts for BOS headquarters and branches was not complete, the revision to the banks' monthly statistical return and the preparation of additional guidelines for completing the revised monthly return were not finalized, and work with the MOF and the line ministries had not progressed on the clarification and classification of government's accounts in monetary statistics.

Following consultation with the authorities during the 2005 Annual Meetings, STA plans to field a follow-up mission on monetary and financial statistics during November 28December 9, 2005. This mission will assist BOS in implementing of recommendations for improving monetary statistics made by the July 2003 mission and in exploring options to expand the existing reporting system to cover the banking activities in the South.

\section{EXTERNAL SECTOR}

Daily exchange rate data are reported to the Fund with minimal lags, but there are several areas for improvement in the external accounts, particularly with regard to foreign direct investment, trade, and oil statistics. The BOS's foreign exchange balances include reserves earmarked for particular purposes such as medicine, oil, and spare part imports, but the composition of these reserves and their potential usability in the event of a balance of payment need is not clear. The authorities need to provide clarification on items that qualify

as international reserves in general, and those earmarked reserves in particular, and should begin compiling the data template on international reserves and foreign currency liquidity. 
Regarding import statistics, there are significant discrepancies between the reports from customs and the BOS. The July 2003 STA mission identified some possible causes of such discrepancies and, in collaboration with authorities, attempted to reconcile the data. The mission reported some progress on implementing the recommendations of the 1999 TA report on balance of payments statistics. However, the lack of survey data continues to affect the compilation of important balance of payments items such as foreign direct investment.

Medium-term oil production projections and data on amortization of private sector debt need substantial improvement. The authorities have made some progress in improving oil projections, but appear reluctant to provide more detailed information on the phasing-in and expected production levels of new blocks and on amortization of debt in the oil sector. Total oil reserves available are estimated between 10 to 15 billion barrels, which, at a production rate of 350 thousand barrels a day, would last about 100 years. 


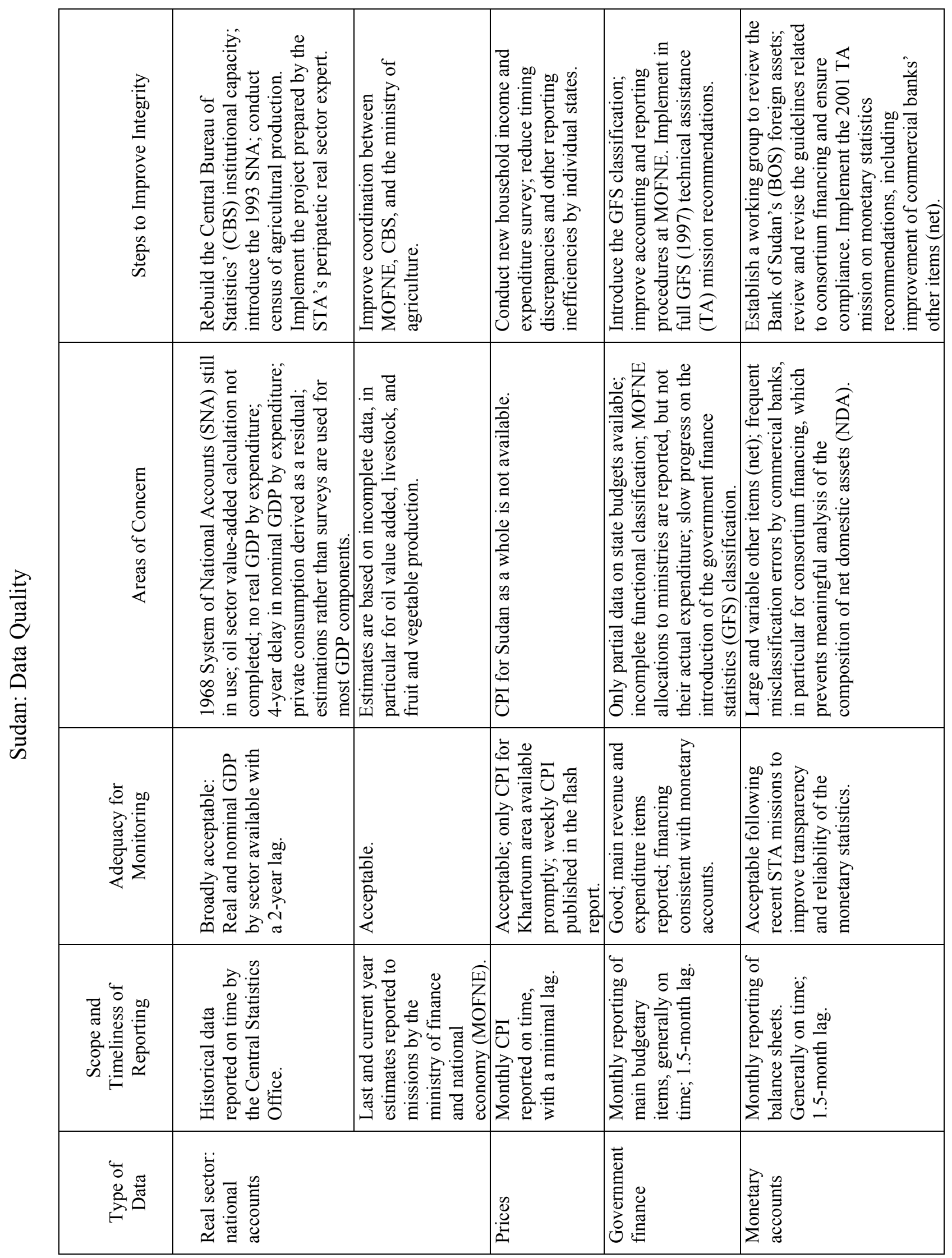




\begin{tabular}{|c|c|c|c|c|c|c|c|}
\hline 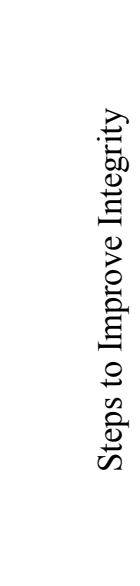 & 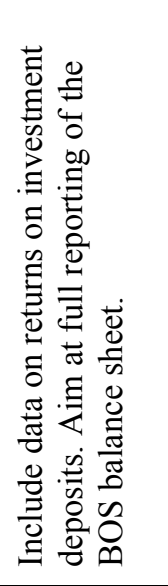 & 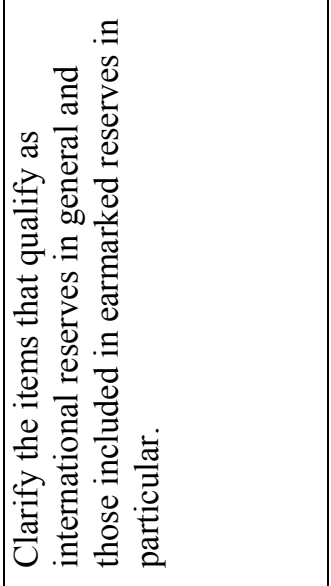 & & 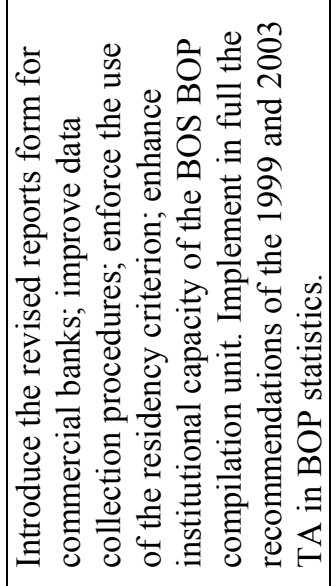 & & 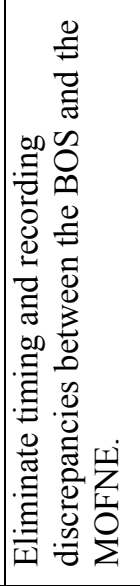 & 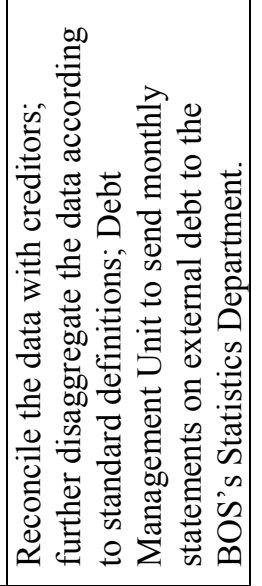 \\
\hline 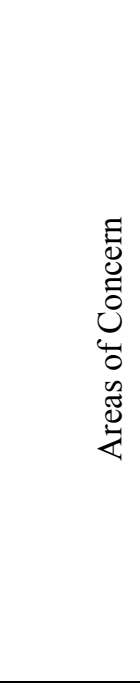 & 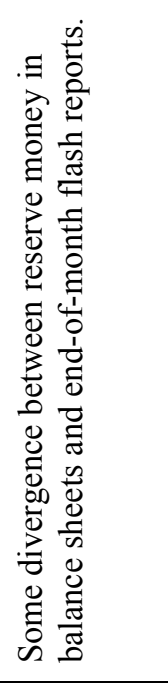 & 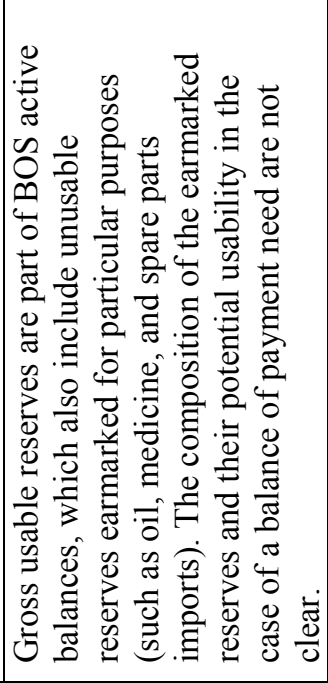 & & 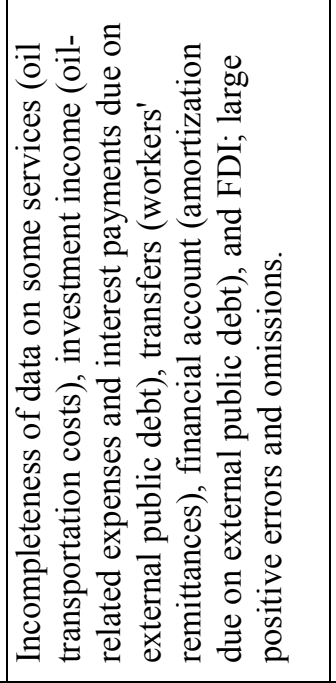 & 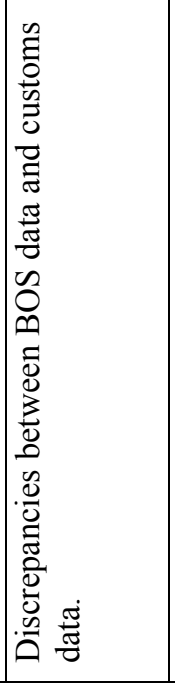 & 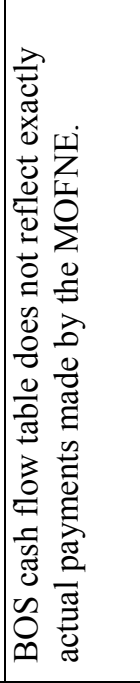 & 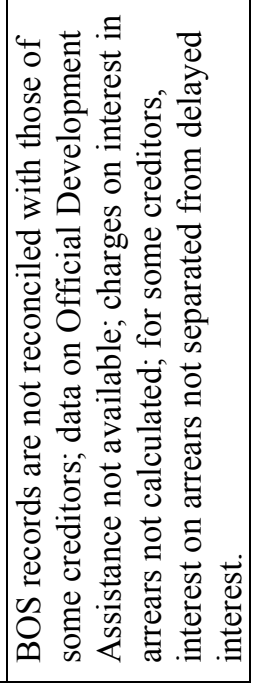 \\
\hline 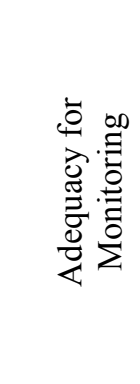 & 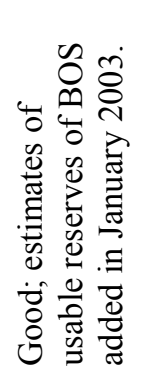 & 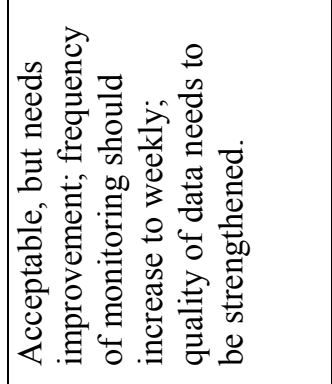 & 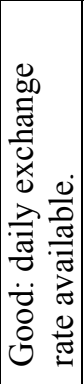 & 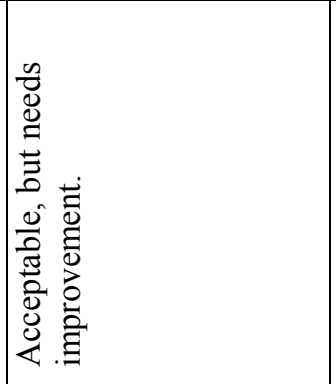 & 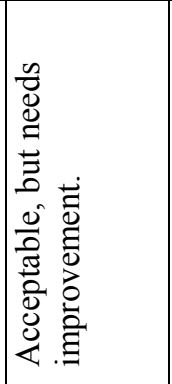 & 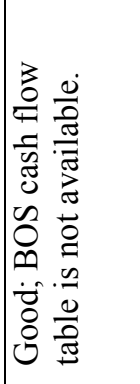 & 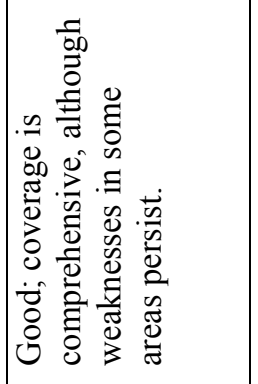 \\
\hline 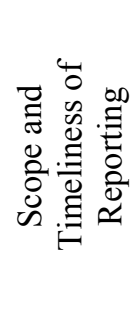 & 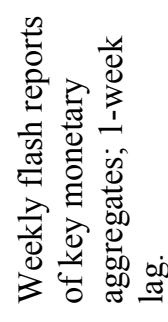 & 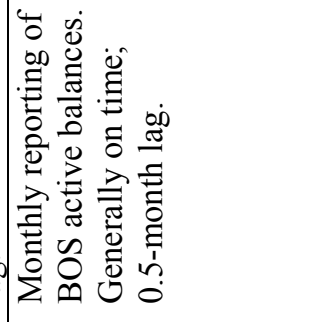 & 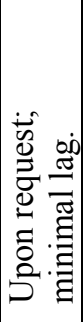 & 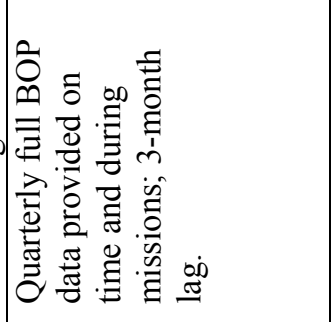 & 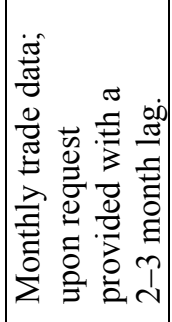 & 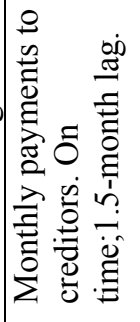 & 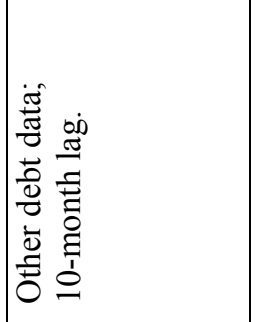 \\
\hline 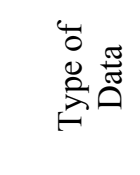 & & 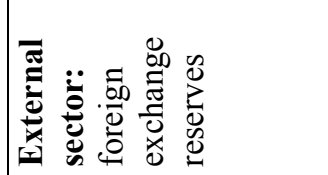 & 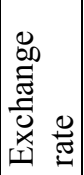 & 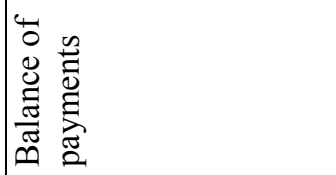 & & 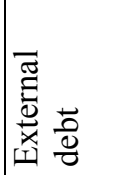 & \\
\hline
\end{tabular}




\section{SUDAN: TABLE OF COMMON INDICATORS REQUIRED FOR SURVEILLANCE} AS OF OCTOBER 20, 2005

\begin{tabular}{|c|c|c|c|c|c|}
\hline & $\begin{array}{c}\text { Date of latest } \\
\text { observation }\end{array}$ & $\begin{array}{l}\text { Date } \\
\text { received }\end{array}$ & $\begin{array}{c}\text { Frequency } \\
\text { of } \\
\text { data }^{6}\end{array}$ & $\begin{array}{l}\text { Frequency } \\
\text { of } \\
\text { reporting }^{6}\end{array}$ & $\begin{array}{r}\text { Frequency of } \\
\text { publication }^{6}\end{array}$ \\
\hline Exchange Rates & $10 / 10 / 05$ & $10 / 10 / 05$ & $\mathrm{D}$ & $\mathrm{D}$ & $\mathrm{D}$ \\
\hline $\begin{array}{l}\text { International Reserve Assets and Reserve Liabilities } \\
\text { of the Monetary Authorities } 1\end{array}$ & $8 / 31 / 05$ & $9 / 20 / 05$ & M & M & M \\
\hline Reserve/Base Money & $8 / 31 / 05$ & $9 / 20 / 05$ & M & $\mathrm{W}$ & $\mathrm{M} / \mathrm{W}$ \\
\hline Broad Money & $8 / 31 / 05$ & $9 / 20 / 05$ & $\mathrm{~W}$ & $\mathrm{~W}$ & $\mathrm{M} / \mathrm{W}$ \\
\hline Central Bank Balance Sheet & $8 / 31 / 05$ & $9 / 20 / 05$ & M & M & M \\
\hline Consolidated Balance Sheet of the Banking System & $8 / 31 / 05$ & $9 / 20 / 05$ & M & M & M \\
\hline Interest Rates ${ }^{2}$ & $9 / 29 / 05$ & $10 / 10 / 05$ & $\mathrm{~W}$ & M & $\mathrm{M} / \mathrm{W}$ \\
\hline Consumer Price Index & August 2005 & $9 / 3 / 05$ & $\mathrm{M} / \mathrm{W}$ & M & M \\
\hline $\begin{array}{l}\text { Revenue, Expenditure, Balance and Composition of } \\
\text { Financing }{ }^{3} \text { - General Government }\end{array}$ & August 2005 & $10 / 3 / 05$ & M & M & M \\
\hline $\begin{array}{l}\text { Stocks of Central Government and Central } \\
\text { Government-Guaranteed Debt }\end{array}$ & June 2005 & Sept. 2005 & A & A & A \\
\hline External Current Account Balance & 2005: Q2 & Sept. 2005 & Q & Q & Q \\
\hline Exports and Imports of Goods and Services & June 2005 & Sept. 2005 & M & M & M \\
\hline GDP/GNP & 2004 & Sept. 2005 & A & A & A \\
\hline Gross External Debt & 2004:Q4 & Feb. 2005 & A & A & A \\
\hline
\end{tabular}

${ }^{1}$ Includes reserve assets pledged or otherwise encumbered as well as net derivative positions.

${ }^{2}$ Both market-based and officially determined, including discount rates, money market rates, rates on treasury bills, notes and bonds.

${ }^{3}$ Foreign, domestic bank, and domestic nonbank financing.

${ }^{4}$ The general government consists of the central government (budgetary funds, extra budgetary funds, and social security funds) and state and local governments.

${ }^{5}$ Including currency and maturity composition

${ }^{6}$ Daily (D); Weekly (W); Monthly (M); Monthly/Weekly (M/W); Bi-monthly (B); Quarterly (Q); Annually (A); Irregular (I); Not Available (NA) 